\title{
التضمنات التربوية في الحوار بين الآباء والأبناء في القرآن الكريم
}

\author{
عبد المحي \\ محاضر جامعة صلاح الدين الأيوبي الإسلامية، جاكرتا \\ Email: Abdulmuhyi06@gmail.com
}

\section{ملخص البحث}

ينطلق هذا البحث من أن القرآن الكريم يتضمن الأصول التربوية. يهدف هذا البحث إلى معرفة القيم البلاغية والتضمنات التربوية للحوار بين الآباء والأبناء في القرآن الكريم. الطريقة المستخدمة في هذا البحث هي طريقة تحليل المضمون. والنتائج من هذا البحث أن الحوار بين الآباء والأبناء في القرآن الكريم تقع في ستة عشر موضعا. والمعنى البلاغي فيه يشتمل على جملة إنشائية منها الأمر والنهي والاستفهام والنداء والتمني التي تخرج عن معناها الأصلي وجملة خبرية التي تخرج عن معناها الأصلي والإيجاز والإطناب والقصر والفصل والوصل والكناية والطباق والجناس والتشبيه والاستعارة والتتميم والمقابلة. فأما القيم التريوية في الحوار بين الآباء والأبناء في القرآن الكريع تشمل المواد الدراسية والطرق أو الأساليب التربوية وأسس المعاملة والاتصال المناسبة في العملية التربوي. المصطلحات الرئيسية: الحوار، القرآن الكريم، القيم البلاغية، القيم التربوية

\begin{abstract}
The research starts from the assumption that the al-Qur'an is the source of the main points of education. The research aims to uncover the stylistic values and educational implications of the conversation between father and son in the verses of the Holy Qur'an. The method used in this research is content analysis. The results showed that the conversation between father and son are available in 16 verses. The stylistic values include the jumlah insyãiyyah like al-amr, an-nahyi, al-istifhãm, an-nidãa, and at-tamanny which is coming out from its original meaning. Additionally, it contains jumlah khabariyyah that comes out from its original meaning, al-îjãz wa 'l-ithnãb, alQasr, al-Fashl wa' l-washl, al-kinãyah, ath-thibãq, al-jinãs, at-tasybîh, al-isti'ärah, at-tatmîm, and al-muqäbalab. While the educational values include the curriculum, teaching methods and techniques, the basics of good relationships and communication.
\end{abstract}

Keywords: Conversation, The Holy Qur'an, Stylistic Values, Educational Values 
عبد المحي

\section{مقدمة}

احتوى القرآن الكريم على أحكم منهج، أعدل أسلوب، صراطا مستقيما لا عوج فيه، يهدي من تبعه للتي هي أقوم، ويحقق القرآن أغراضه بعرض الفكرة بأساليب مختلفة ومتعددة. ومن الأساليب التي انتهجها أسلوب الحوار. الحوار هو حديث يجري بين اثنين أو أكثر. وهو بوصفه تركيبا له أسرار

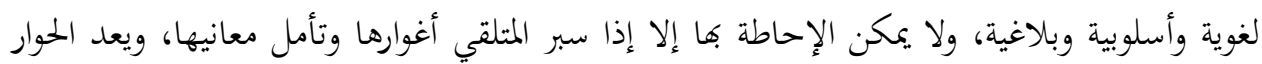
من الأساليب الفنية التي تساعد في تصوير الأحداث الماضية ونقلها إلى الملتقي كما لوكان حاضرا. الحوار القرآي وما يحمله من أفكار وأحاسيس يسير في ابتاهين: الأول: طريق العنف و القسوة كما في حوار ابني آدم الذي تضارعت فيه الألفاظ فيما بينها

$$
\text { لتحتل موقعا يناسب الحدث فكانت فهايته القتل. }
$$

والثاني: طريق اللين والشدة والموعظة الحسنة، كما في حوار الله تعالى مع أنبيائه ورسله، وحوار الأنبياء والرسل مع أقوامهم، وحوار المؤمنين مع الكافرين. ويمكن للمتلقي الكشف عن أسرار الحوار اللغوية والأسلوبية والبالاغية من خلال سماته التركيبية وقرائنه السياقية. وللحوار القرآين سمات تميزه عن أي حوار آخر، يستمدها من تميز أسلوب القرآن الكريم كله، فهو يصور الوقائع والأحداث على أكمل وجه، وأتم مراد. وفيما يلي عرض لجملة من هذه السمات :

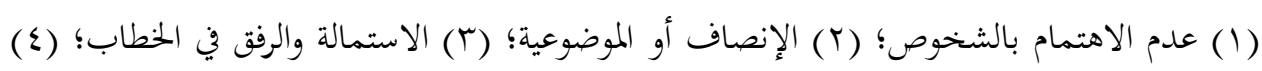

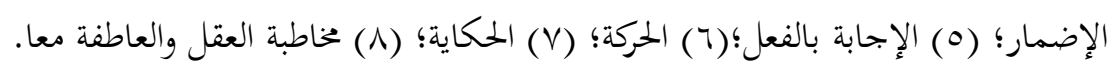
وورد ذكر مشتقات كلمة أب: 111 إ مرة في القرآن الكريم، كما ذكرت مشتقات كلمة الابن والبنت: عا ا مرة (محمد فؤاد عبد الباقي: د.ت). وقد جاء الحوار في القرآن الكريم في مواطن كثيرة على نوعين، الأول: ذكر مشتقات مادة-حور -، والثاني: حكاية ما جرى بين أطراف الحوار دون

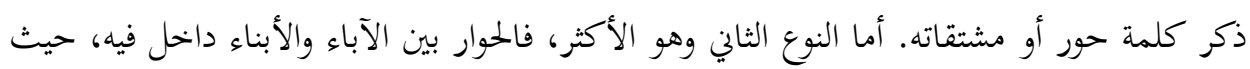
ورد في ستة عشر موضعا، توزعت بين تسع سور من سور القرآن الكريم واحتوت على عدد كبير من بـ

$$
\text { القيم التربوية، التي ذكرت في المبحث الحالي. }
$$

وقد سار الباحث في دراسة الآيات على النحو التالي:

ا ـ رتبت مواضع الحوار وفق ترتيب ورودها في المصحف الشريف؛

r. في كل موضع تأخذ الكلمات الرئيسية التي تضمنت ذلك الحوار، ثم تحلل تلك الكلمات بتحليل

$$
\text { البلاغة وعلم اللغة الاجتماعي؛ }
$$


r. أما القيم التربوية تأخذ من الآيات وفوائد الكلمات المعينة في ذلك الحوار على حسب التحليل البلاغي وعلم اللغة الاجتماعي؛

ع. قد يكثر ذكر كلمة “"الآباء” في القيم التربوية، والمقصود به كلا الوالدين الأب والأم. وكذلك الأك

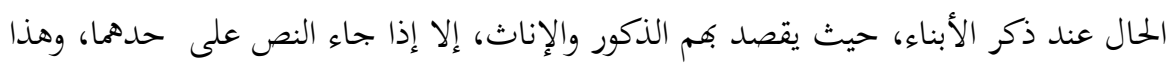

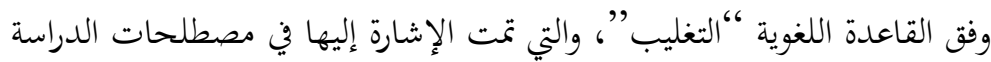

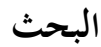

التحليل البلاغي وعلم اللغة الاجتماعي للحوار بين الآباء والأبناء في القرآن الكريم

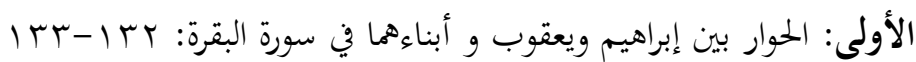

\begin{tabular}{|c|c|c|}
\hline التحليل البلاغي & الآيات & الرقم \\
\hline النداء للاستعطاف والحبر الابتدائي، فائدة الخبر. & 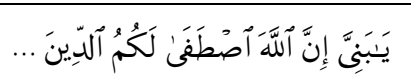 & 1 \\
\hline
\end{tabular}

إيجاز بليغ، والمعنى: الزموا الإسلام ودوموا عليه ولا تفارقوه

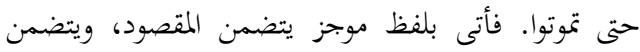
وعظا وتذكيرا بالموت، وذلك أن المرء يتحقق أنه يموت ولا

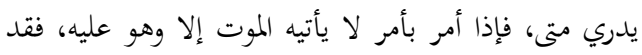

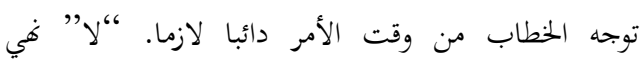

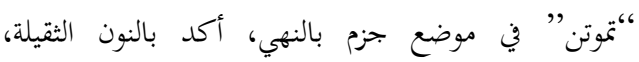
وحذفت الواو لالتقاء الساكنين.

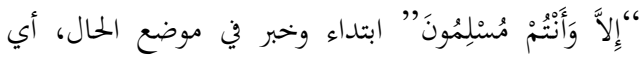

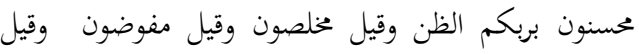

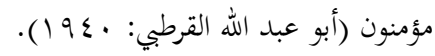

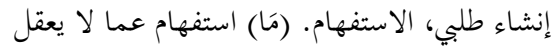

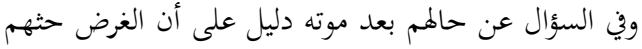

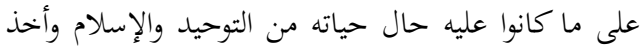
الميثاق منهم عليه فليس الاستفهام حقيقيا (الألوسي: . (1910

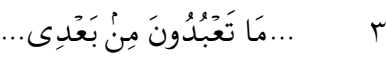
وقال السكاكي يسأل بـ “ما” عن الجنس وفيه “ما تعبدون

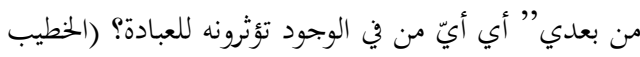

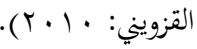




\begin{tabular}{|c|c|c|}
\hline 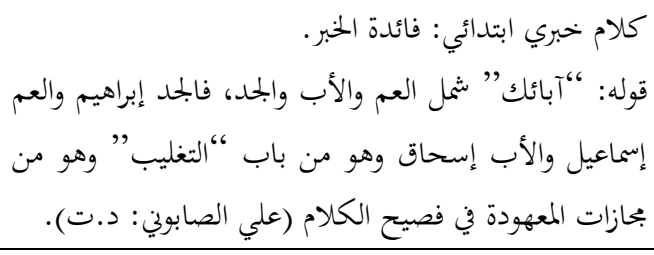 & 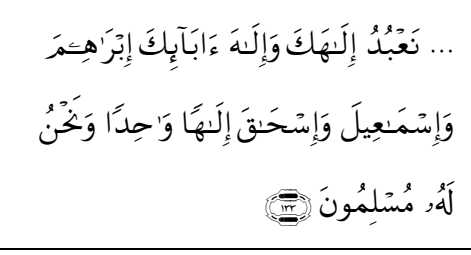 & $\varepsilon$ \\
\hline & لأنعام: V \& الحوار بين إبراهيم وأبوه & 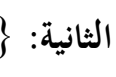 \\
\hline التحليل البلاغي & الآيات & الرقم \\
\hline \multicolumn{3}{|l|}{ مغعولان لتتخذ وهو استفهام فيه معنى الإنكار (القرطبي: } \\
\hline الخبر توبيخا لأبيه وقومه. & 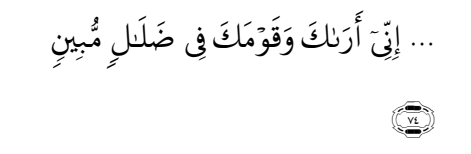 & $r$ \\
\hline
\end{tabular}

\begin{tabular}{|c|c|c|}
\hline \multicolumn{3}{|c|}{ الثالثة: الحوار بين نوح وابنه في سورة هود: rع -بrع } \\
\hline التحليل البلاغي & الآيات & الرقم \\
\hline 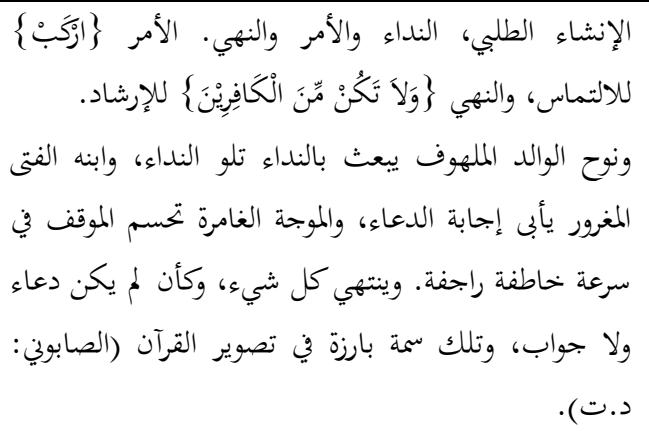 & 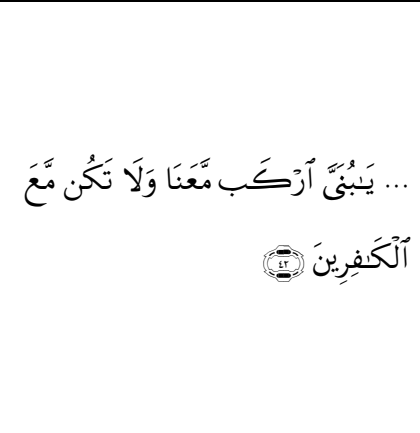 & 1 \\
\hline 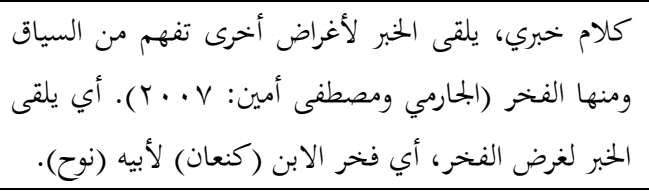 & 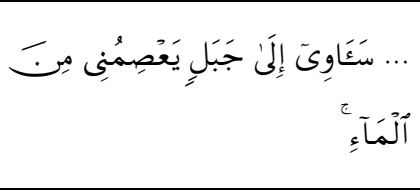 & $r$ \\
\hline 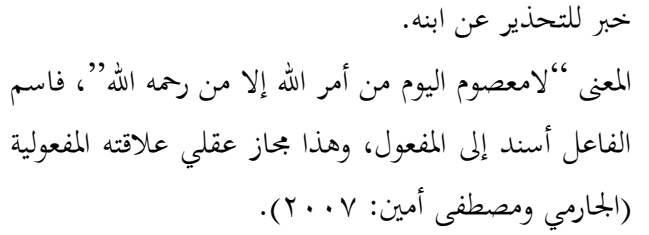 & 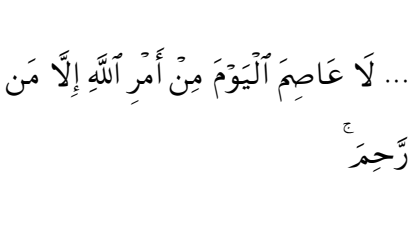 & $r$ \\
\hline
\end{tabular}


الرابعة: الحوار بين يوسف وأبوه في سورة يوسف: ع-ه

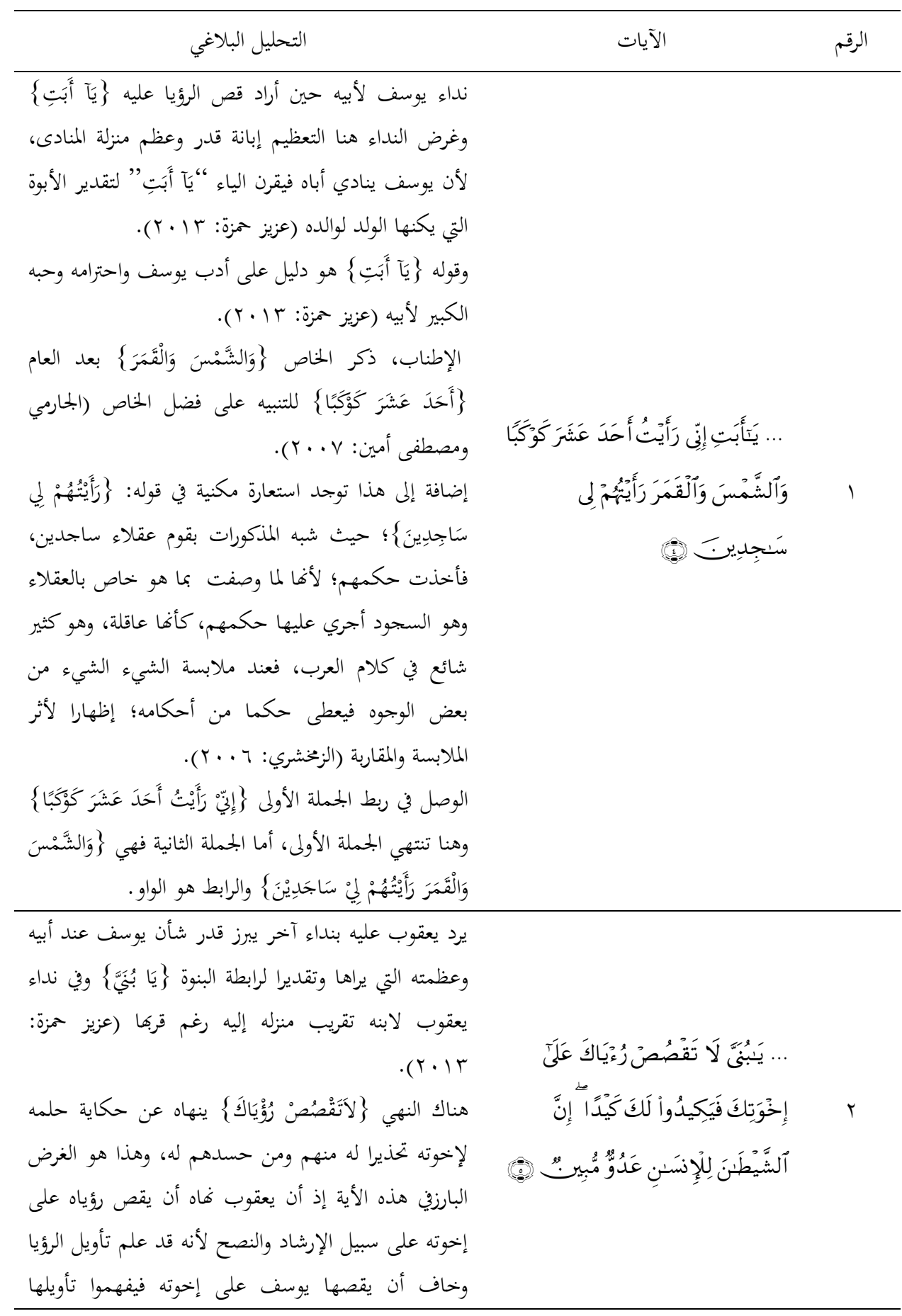


السادسة: الحوار بين يعقوب وأبناءه في سورة يوسف: 7 | |-1 |

\begin{tabular}{|c|c|c|}
\hline التحليل البلاغي & الآيات & الرقم \\
\hline 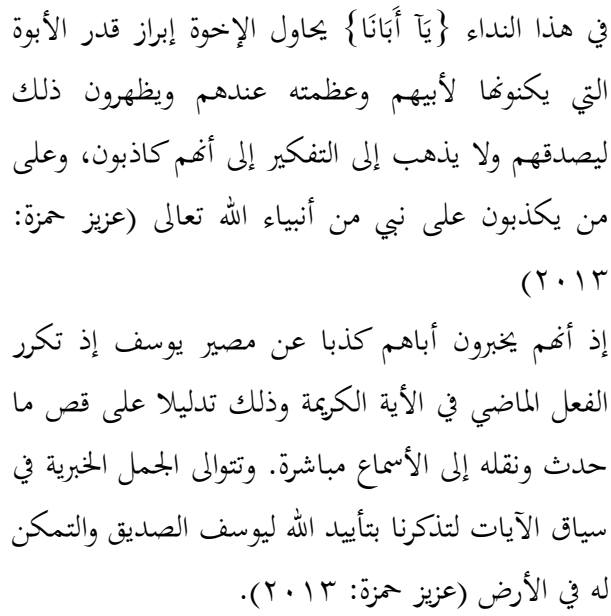 & 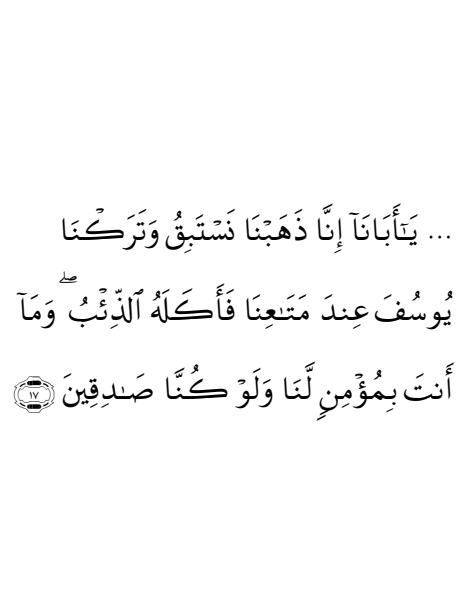 & 1 \\
\hline 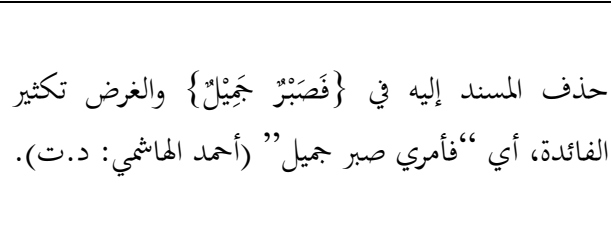 & 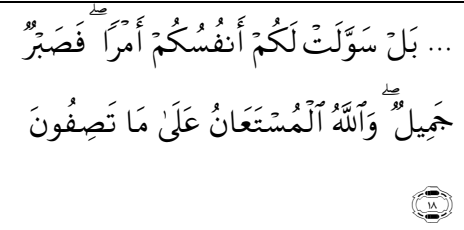 & $r$ \\
\hline
\end{tabular}

السابعة: الحوار بين يعقوب وأبناءه في سورة يوسف: بT-

\begin{tabular}{lll}
\hline الرقم & الرآياتة \\
\hline
\end{tabular}

النداء $\}$ يَاَ أَبَانَا هنا إشارة إلى علو المنادى وعظم

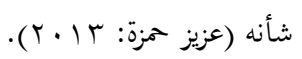

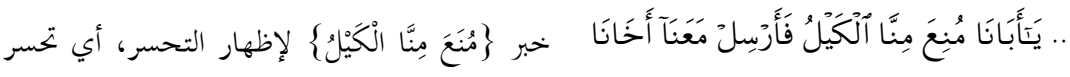

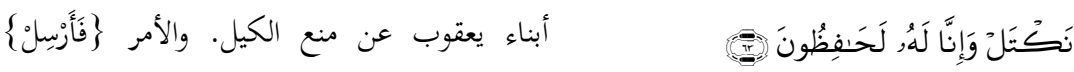

$$
\text { لالتماس. }
$$

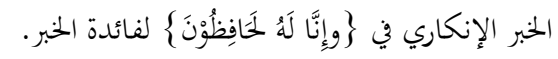

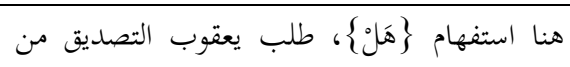

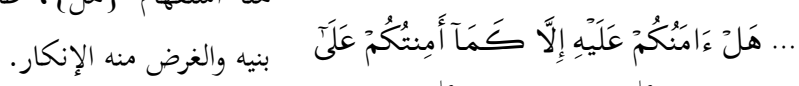

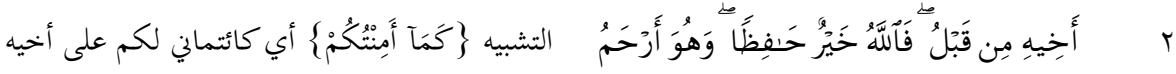

من قبل يوسف، شبه ائتمانه لهم على الأخ الأصغر

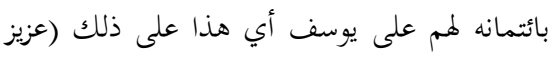

(ألرَّ人ِين 


\begin{tabular}{|c|c|c|}
\hline حمزة: r| (Y). & & \\
\hline 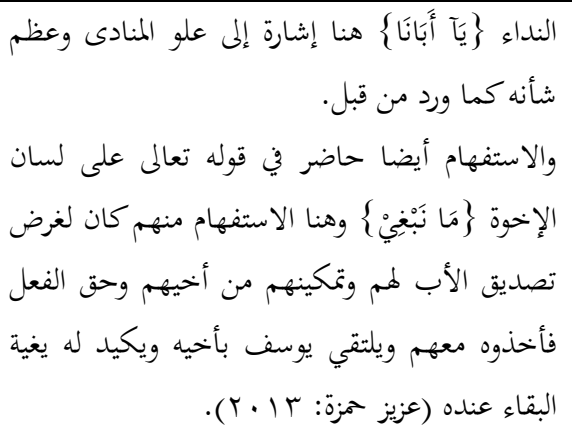 & 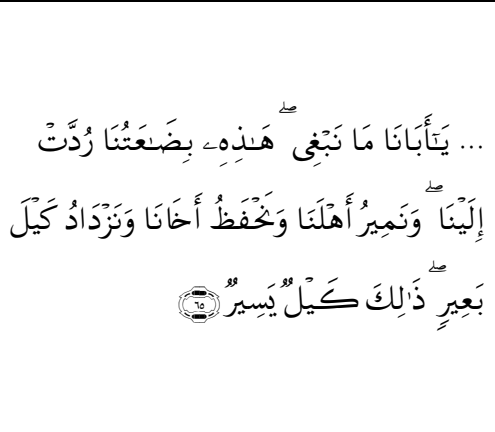 & $r$ \\
\hline
\end{tabular}

الكناية $\}$

$$
\text { هي إحاطة العدو (عزيز حمزة: با • ب). }
$$

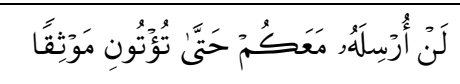

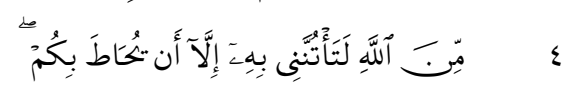

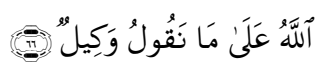

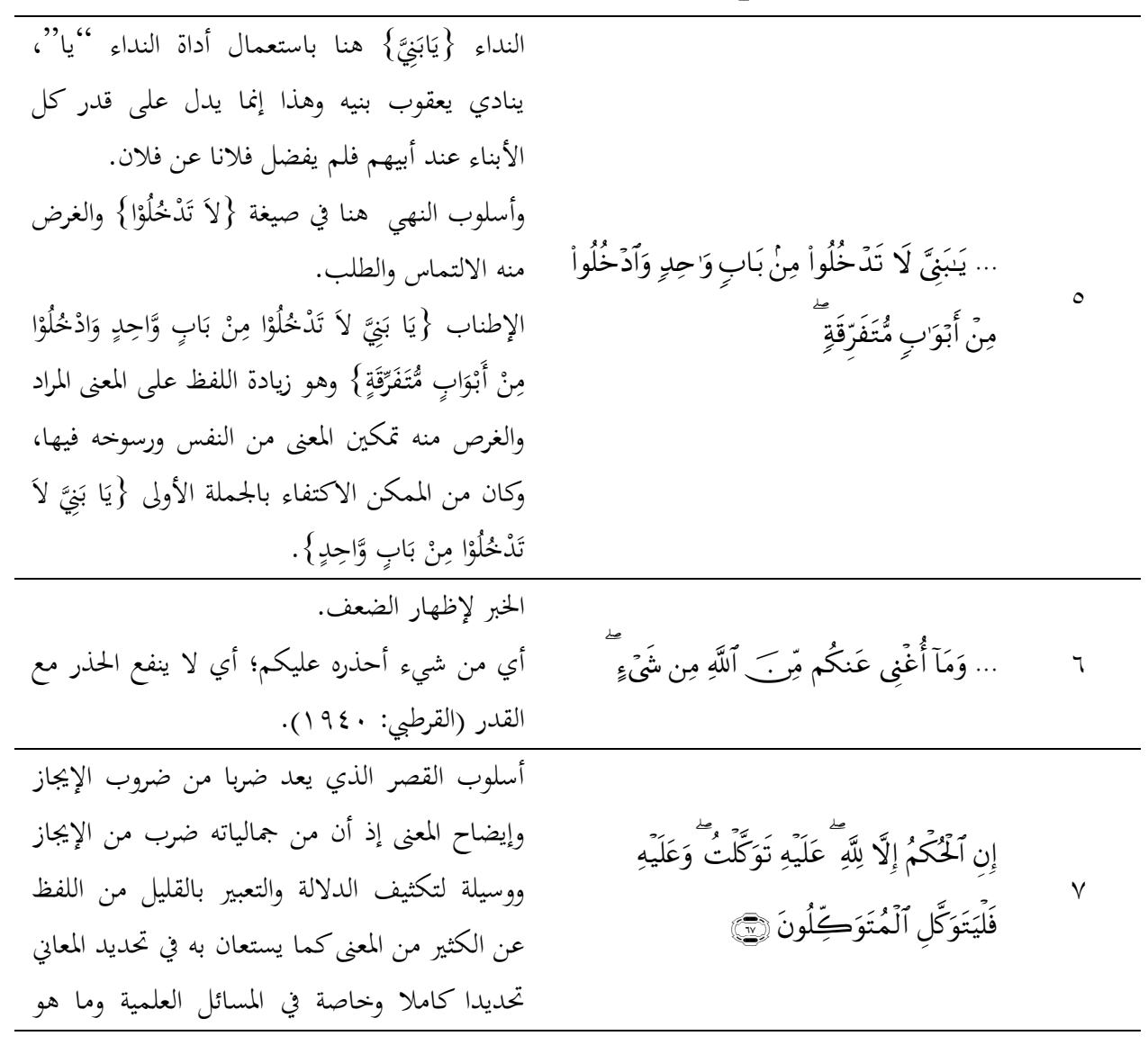




$$
\text { قريب منها (العاكوب: 1999) (199). }
$$

الثامنة: الحوار بين يعقوب وأبناءه في سورة يوسف:

الرقم

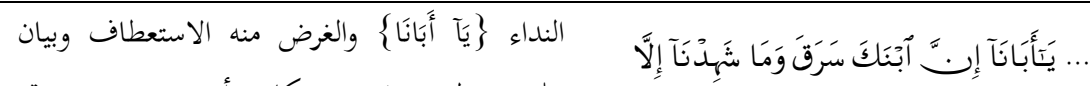

علو وعظمة وقدر ومكانة أبيهم (عزيز حمزة:

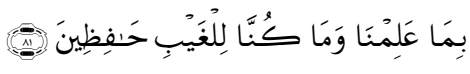

المحاز المرسل \} القرية\{ يراد بها أهلها، وعلاقته المحلية

$$
\text { (علي الجارمي ومصطفى أمين، V · . . م). }
$$

يتكرر البحاز المرسل في هذه الآية الكريمة، فسؤال القرية عبارة عن سؤال أهلها بحازا في القرية لإطلاقها

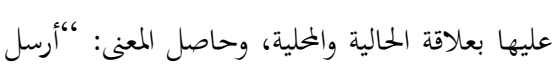

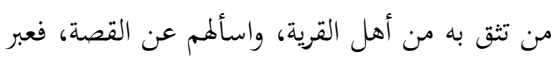

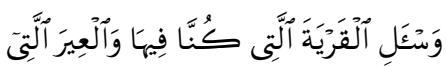

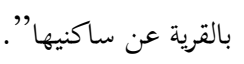

الإِيجاز

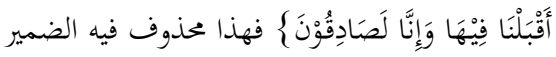

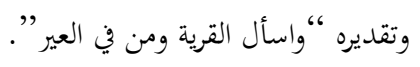

حذف المسند إليه في

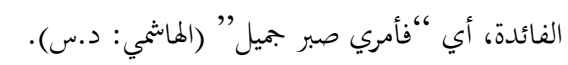

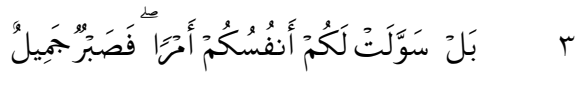

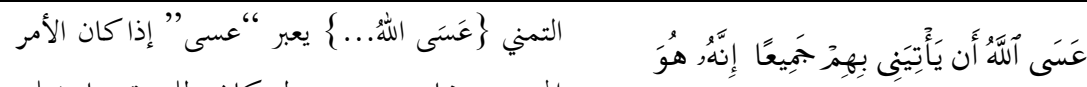
المحجوب مما يرجى حصوله كان طلبه ترجيا (علي الهي

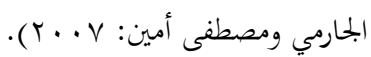

$$
\begin{aligned}
& \text { النداء }\}
\end{aligned}
$$

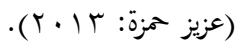

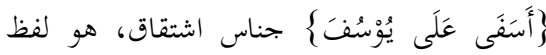

$$
\begin{aligned}
& \text { أسف ويوسف (عزيز حمزة: rا • (T). }
\end{aligned}
$$

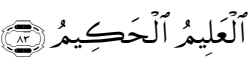

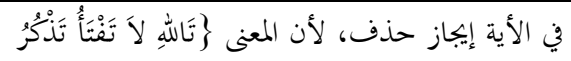

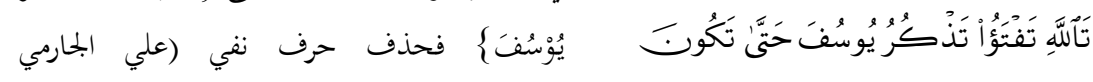

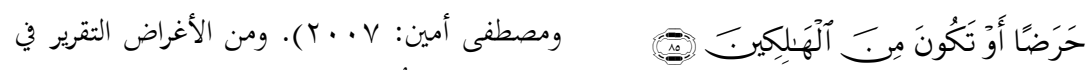

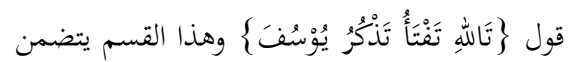


خبرا بحيث يتضمن حذف النص لأنه لا يأتي إلا

بإباثبات.

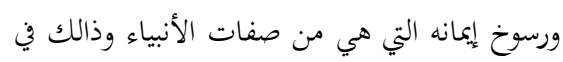

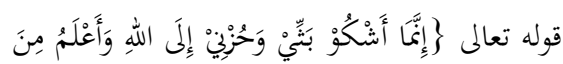

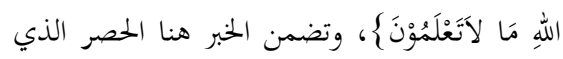

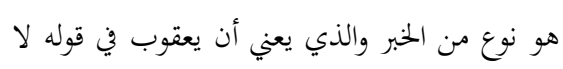
أشكو إلى أحد منكم إنما أشكو إلى ربي إلى دائما

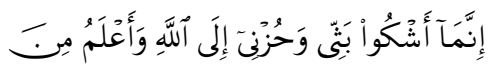

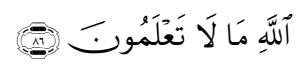
وداعيا له وملتجئا إليه فخلوني وشكايتي (عزيز حمزة:

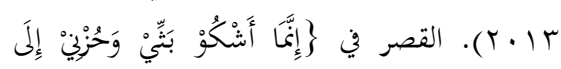
اللِّ

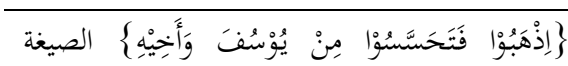

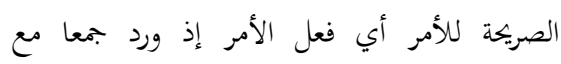
الجماعة المخاطبة للطلب وهو من الإنشاء الطلبي.

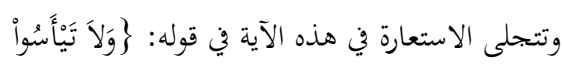

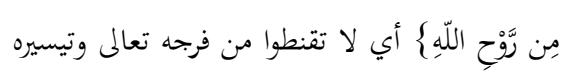
م

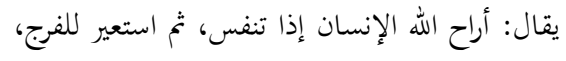

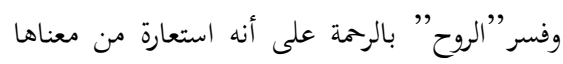

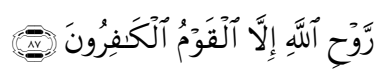

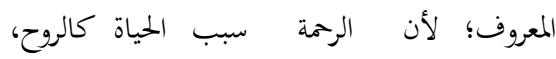

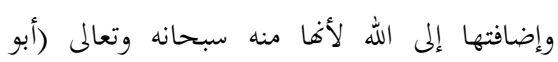

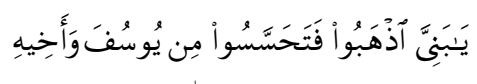
موسى: د.س).

التاسعة: الحوار بين يعقوب وأبناءه في سورة يوسف: ؟حم-q

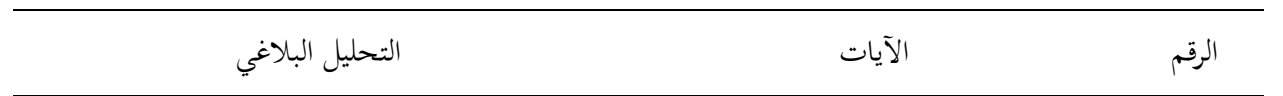

\begin{tabular}{|c|c|c|}
\hline 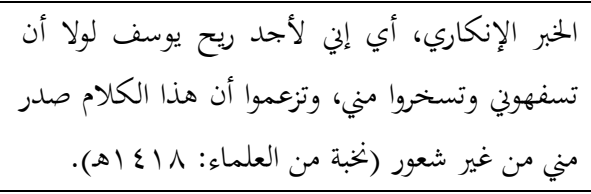 & 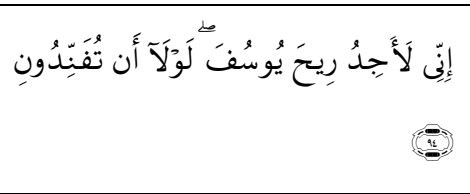 & 1 \\
\hline 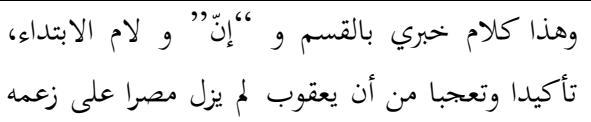 & 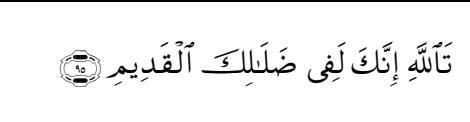 & r \\
\hline
\end{tabular}




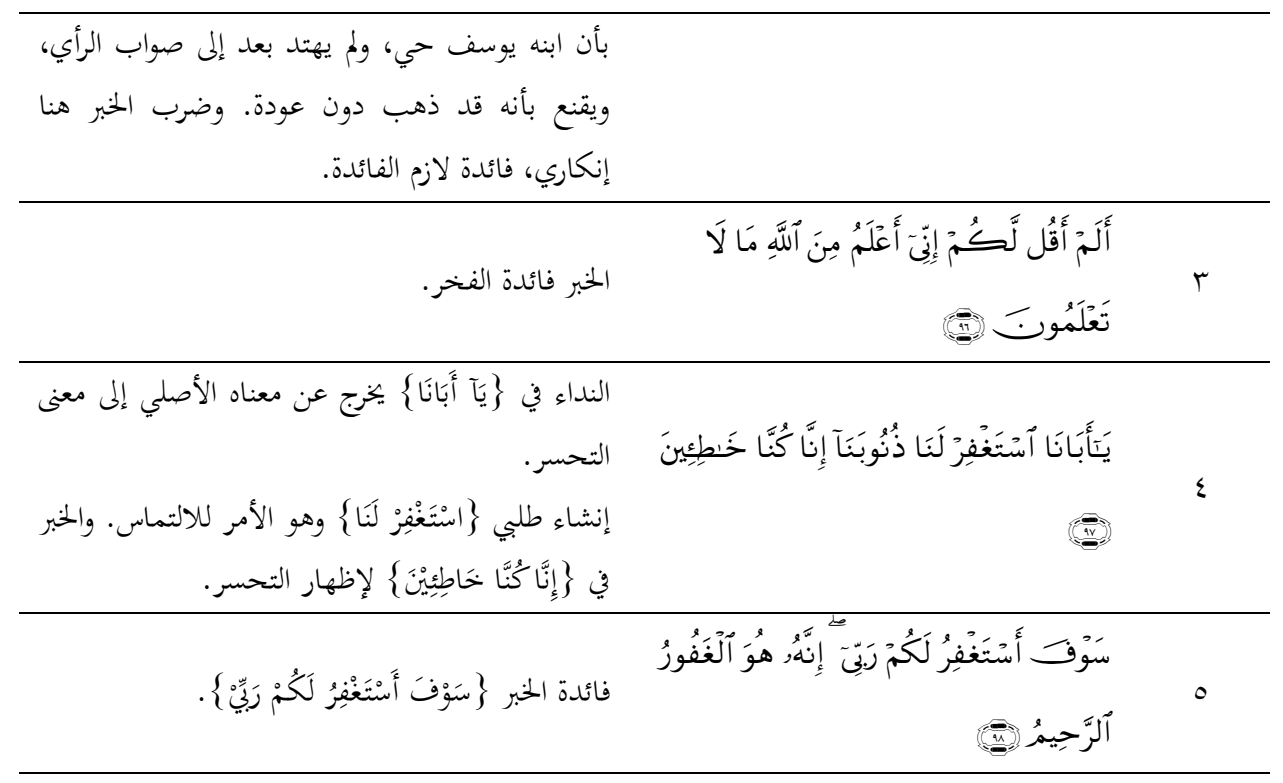

العاشرة: الحوار بين يوسف وأبوه في سورة يوسف: 99-. . 1

\begin{tabular}{lll}
\hline الرقم & التحليل الببلاغي \\
\hline
\end{tabular}

اذِ

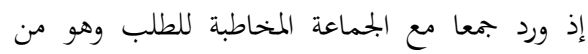

$$
\text { الإنشاء الطبلي. }
$$

ويتضح المحاز المرسل جليا في هذه الآية في قوله:

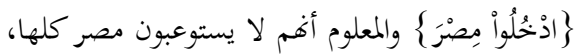

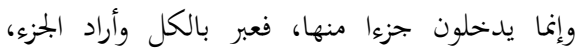

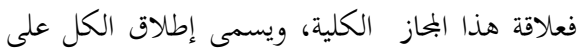

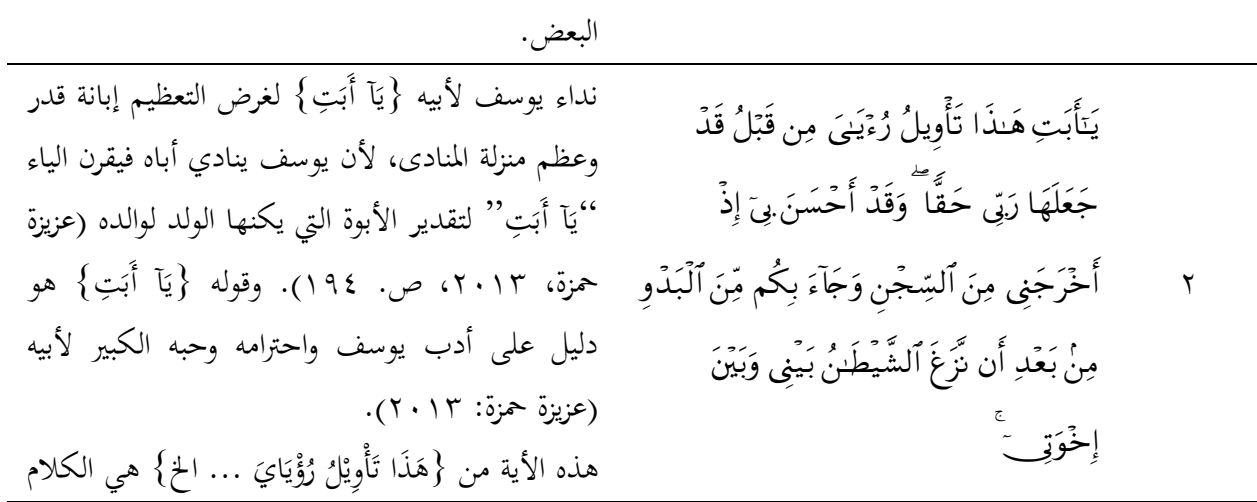




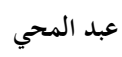

\begin{tabular}{|c|c|c|}
\hline \multicolumn{3}{|l|}{ 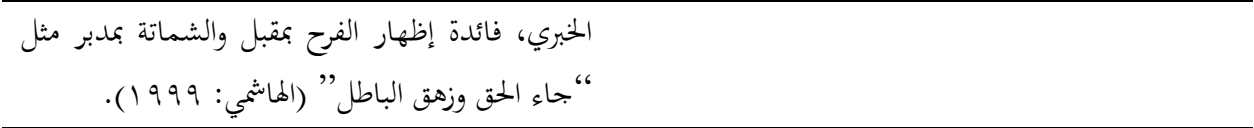 } \\
\hline فائدة الخبر. & 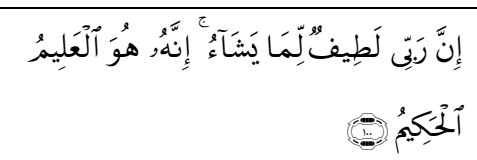 & $r$ \\
\hline$\{\wedge-\varepsilon 1$ & رو: الحوار بين إبراهيم وأبوه في سورة مري & 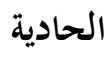 \\
\hline التحليل البلاغي & 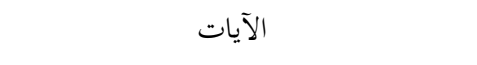 & 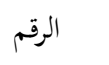 \\
\hline 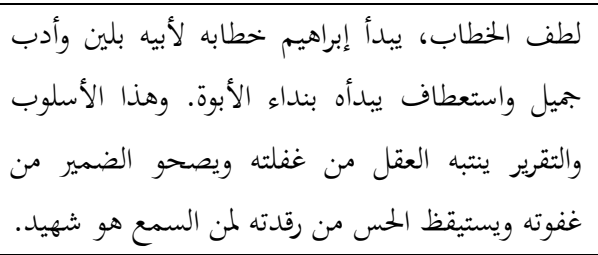 & 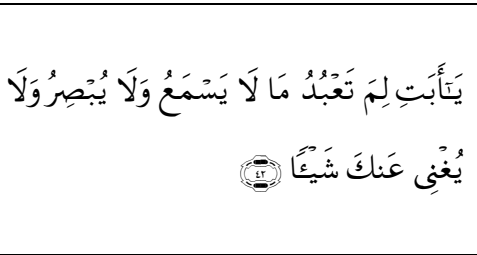 & 1 \\
\hline في النداء للاستعطاف والتوسل إليه، وهناك التنبه والتنبيه & 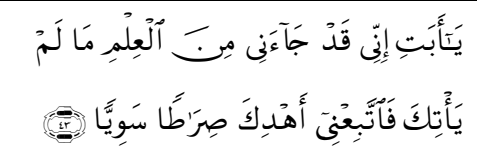 & $r$ \\
\hline النداء للاستعطاف والنهي للإرشاد. & 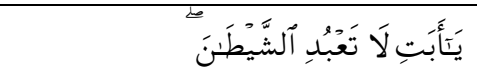 & r \\
\hline مستك براعب للإرشاد، أي أن الشيطان كان للرحمن مخالفا & 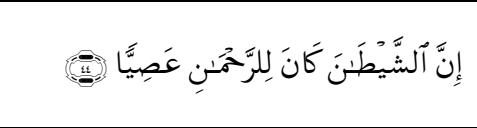 & $\varepsilon$ \\
\hline 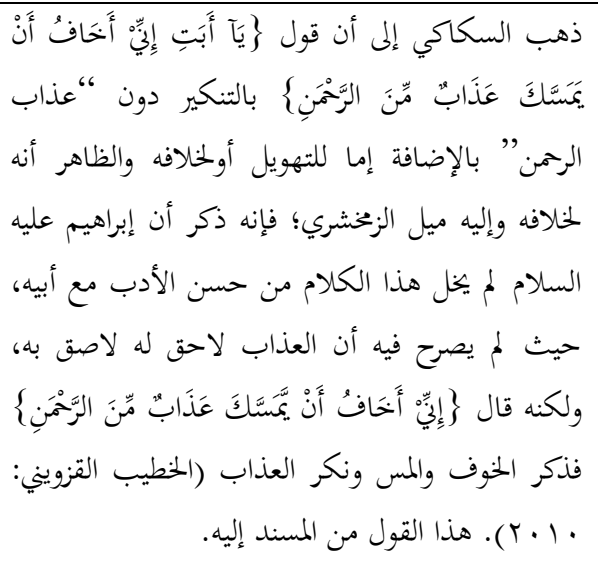 & 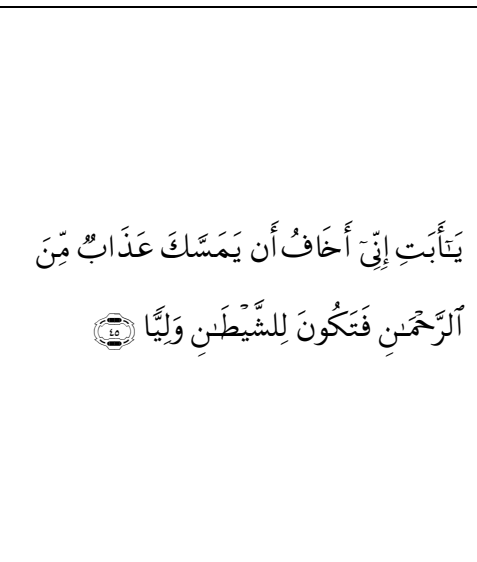 & 0 \\
\hline 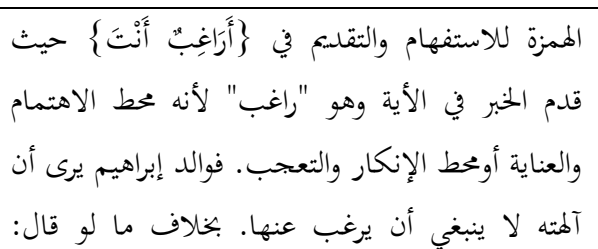 & 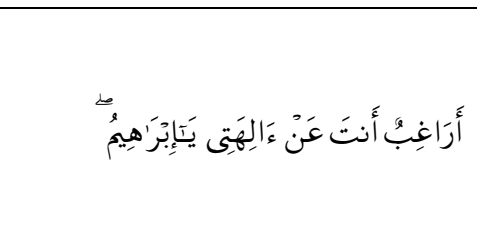 & 7 \\
\hline
\end{tabular}




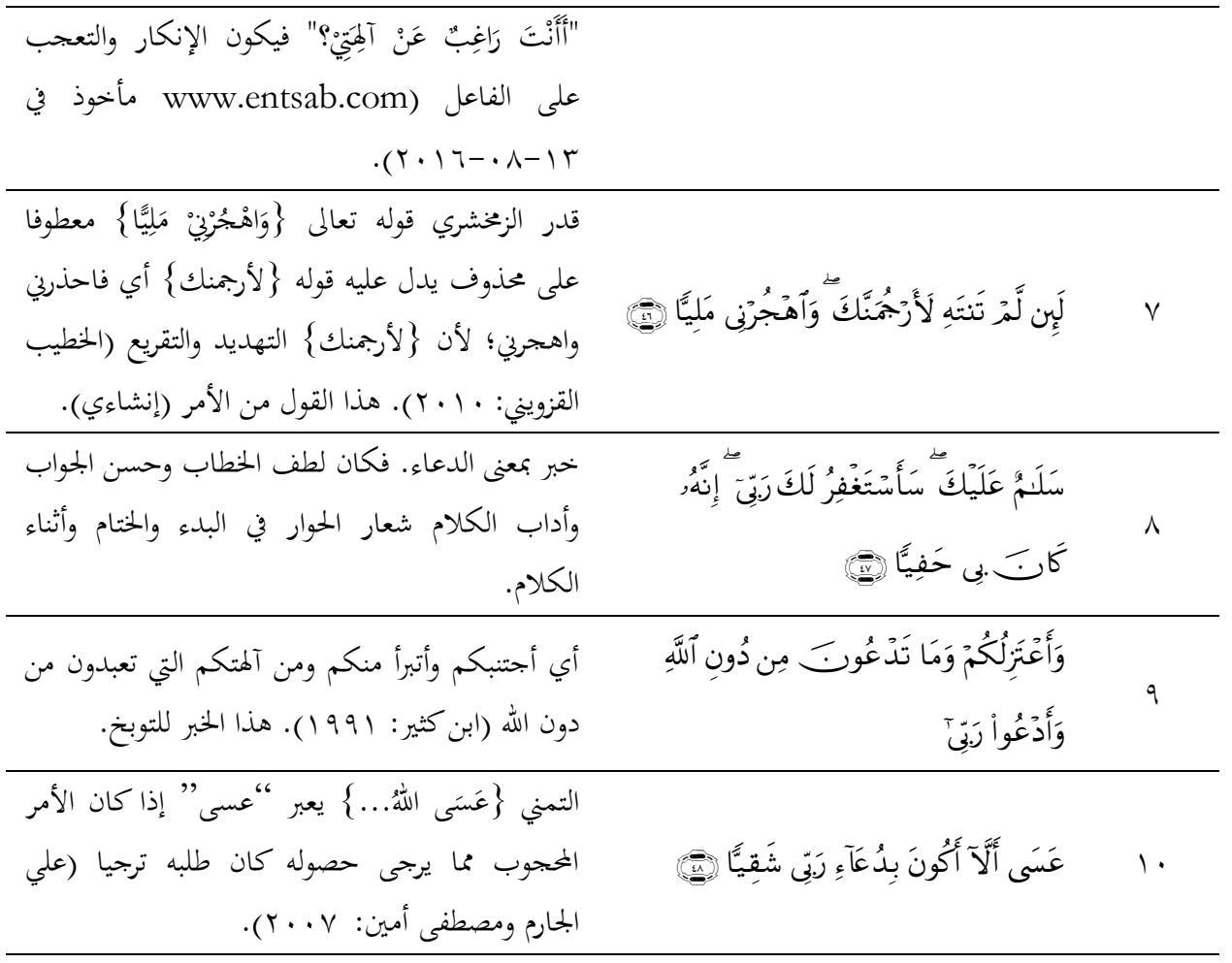

الثانية عشر: الحوار بين أخت موسى وأمها في سورة القصص: 11

\begin{tabular}{|c|c|c|}
\hline التحليل البلاغي & الآيات & الرقم \\
\hline
\end{tabular}

$$
\text { الأمر للإرشاد. }
$$

أمر الله تعالى أم موسى أن تلقيه في اليم ولا لأل

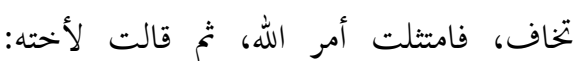

اتبعي أثر موسى كيف يصنع به؟ فتتبعت أثره

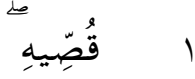

فأبصرته عن بعد، وقوم فرعون لا يعرفون أهما

أخته، وأها تتبع خبره (نخبة من لهن العلماء:

( ) ( ) $\leqslant 11$

الثالثة عشر: الحوار بين بنت صاحب مدين وأبوها في سورة القصص: جب

\begin{tabular}{|c|c|}
\hline التحليل البلاغى & الآيات \\
\hline
\end{tabular}




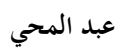

\begin{tabular}{|c|c|c|}
\hline 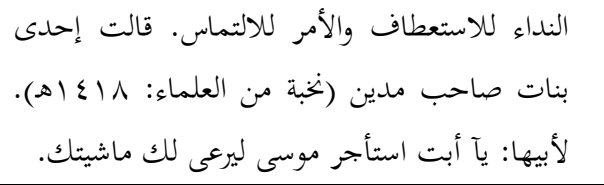 & 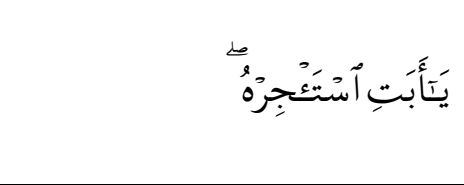 & 1 \\
\hline 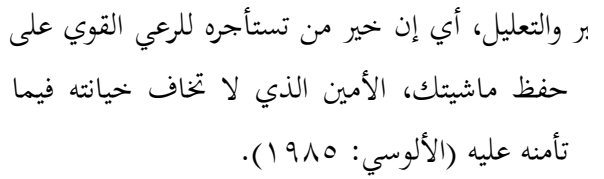 & 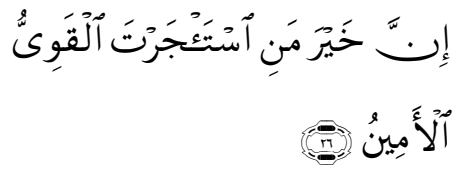 & $r$ \\
\hline
\end{tabular}

\begin{tabular}{|c|c|c|}
\hline التحليل البلاغي & الآيات & الرقم \\
\hline بأ بأ بالتحذير له فله من الشئدة الإرشاد. & 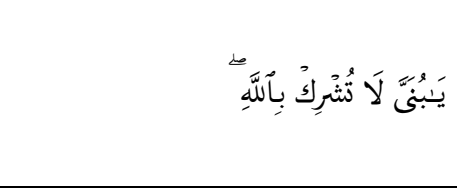 & 1 \\
\hline التعليل للنهي. النيل & 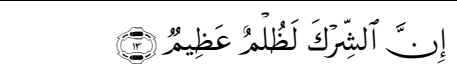 & r \\
\hline 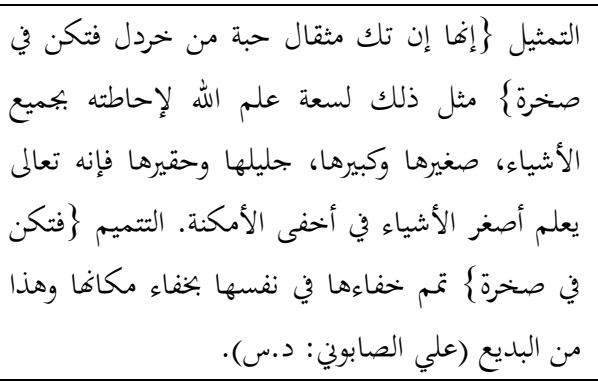 & 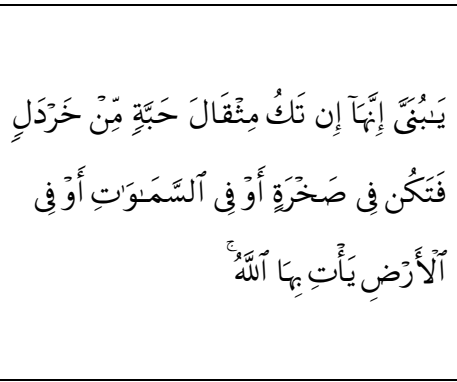 & $r$ \\
\hline المبالغة (علي الصابوني : د.س). & إِنَّ الَلَّهَ لَطِيفُ خَبِير & $\varepsilon$ \\
\hline 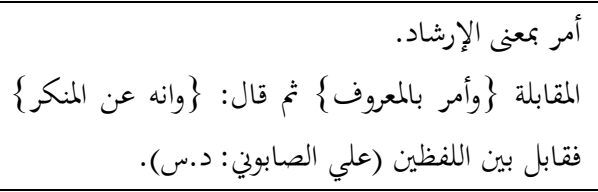 & 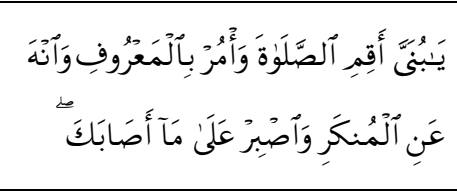 & 0 \\
\hline التعليل للأمر. & إِنَّ ذَلِكَ مِنْ عَزْم آلَالَُُعْورِ & 7 \\
\hline 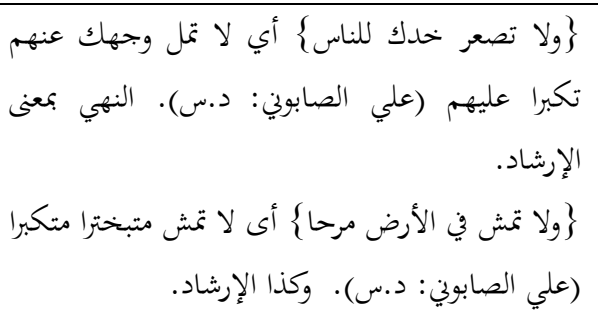 & 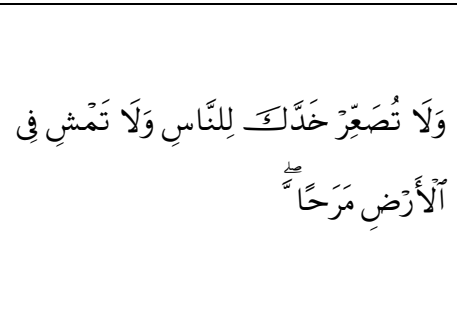 & V \\
\hline
\end{tabular}




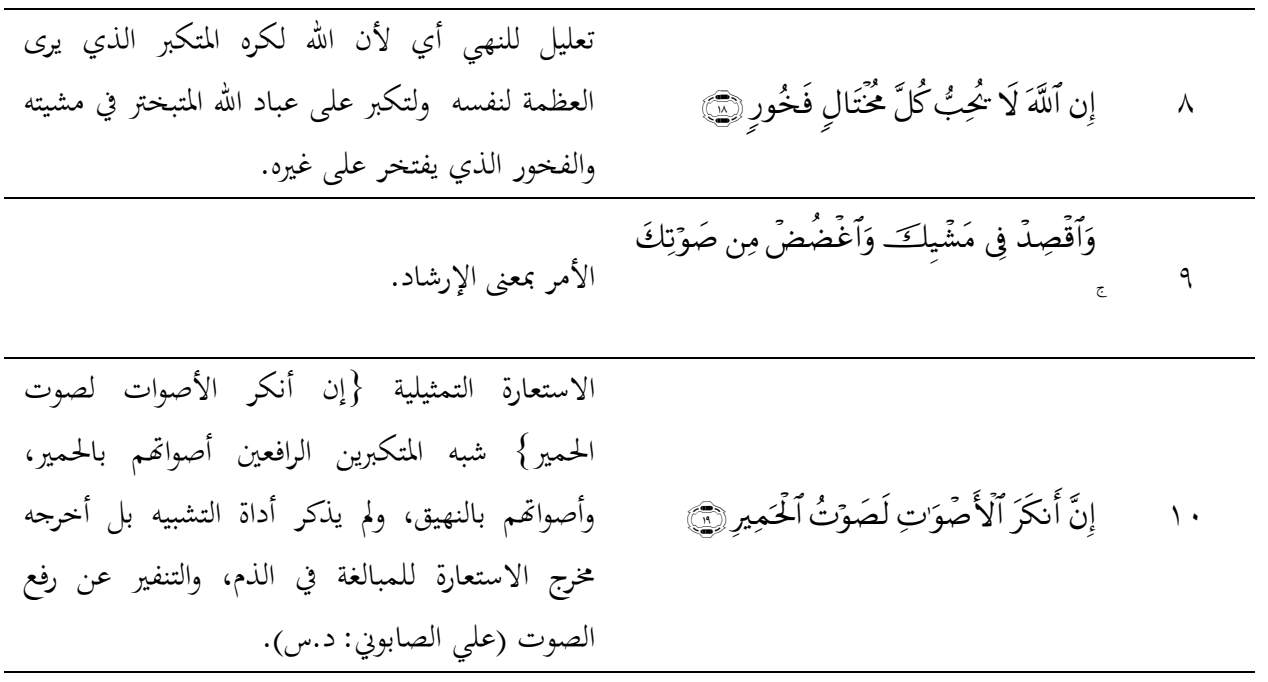

الخامسة عشر: الحوار بين إبراهيم و ابنه إسماعيل في سورة الصفات: ب · ا

\begin{tabular}{|c|c|c|}
\hline التحليل البلاغي & الآيات & الرقم \\
\hline الندء للاستعطاف والخبر لإفادة المخاطب. & 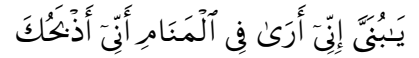 & 1 \\
\hline
\end{tabular}

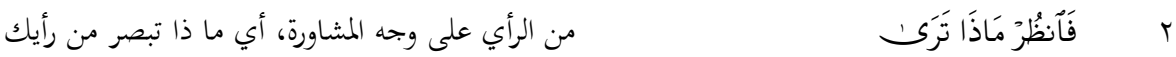

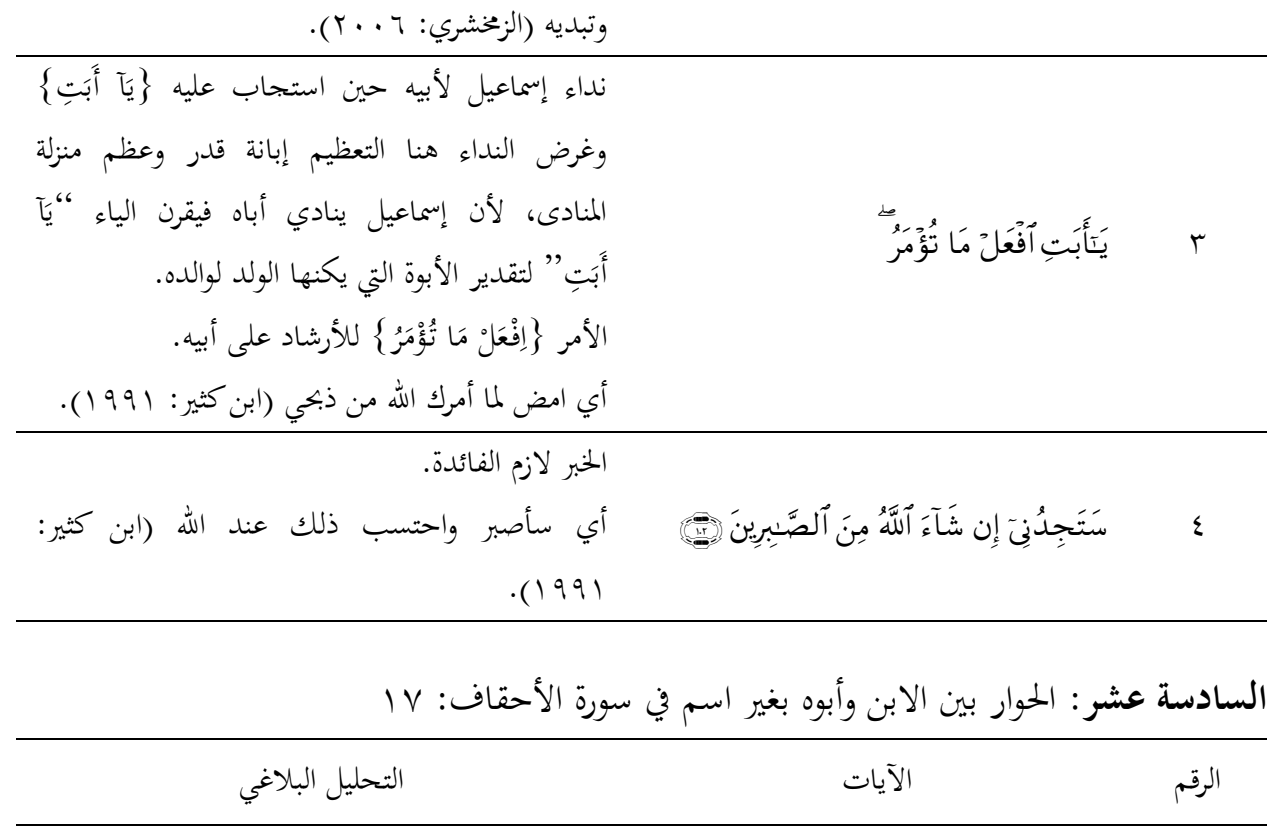


عبد المحي

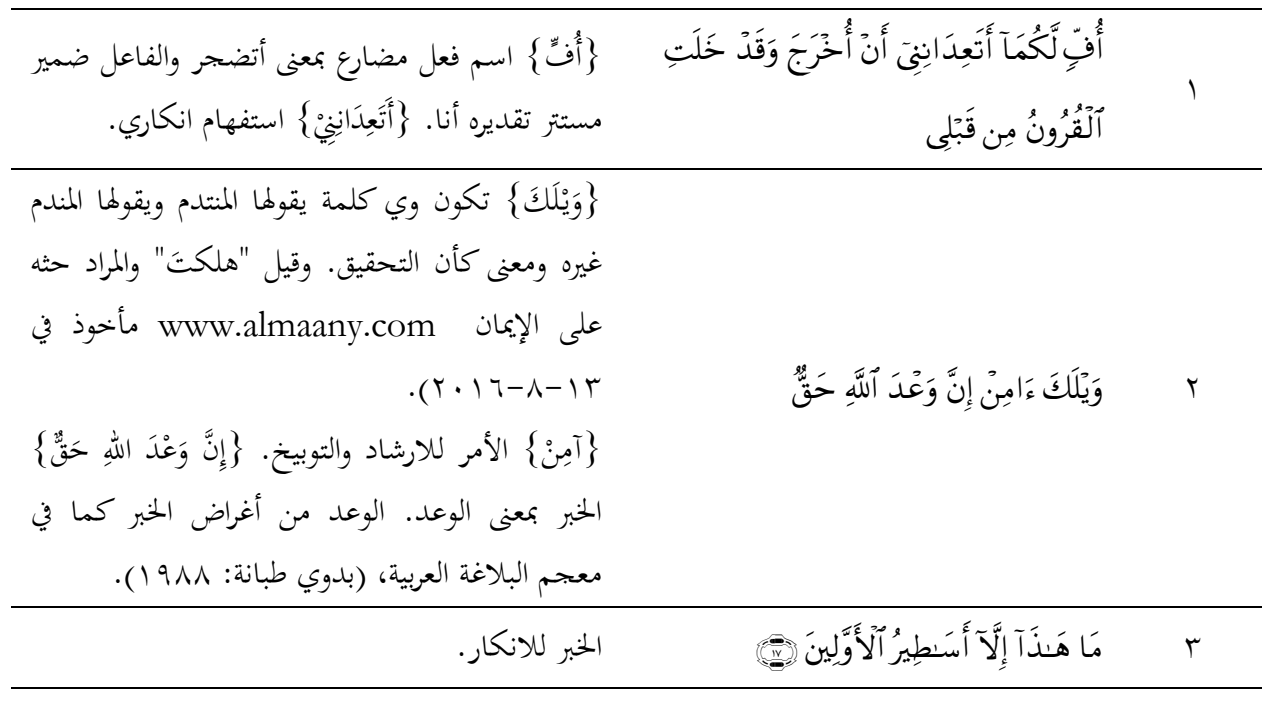

\section{القيم التربوية في الحوار بين الآباء والأبناء في القرآن الكريم \\ أ- ناحية المادة الدراسية}

بلغت الآيات التي ذكر فيها الحوار بين الآباء والأبناء في القرآن الكريم في ستة عشر موضعا، تناولت عددا من الموضوعات التالية التي تصير موادا دراسية في العملية التربوية سواء كانت بين الآباء والأبناء أو بين المدرس والطلاب، وهي: ا. . الدعوة إلى التوحيد، وهو الموضوع الأكثر تناولا فيها، وكذا موضوع أساسي للقرآن الكريم عموما، ولكنه استحوذ على النسبة الأكبر بين المواضع في الحوار بين الآباء والأبناء، حيث بلغ عدد المواضع التي تناولته ستة مواضع، بنسبة الثلث من بحموع عدد الحوارات، وذلك في الحوار بين

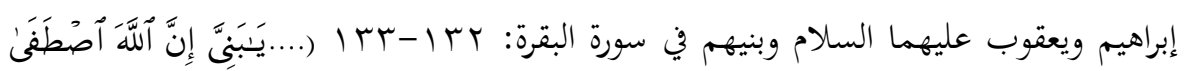

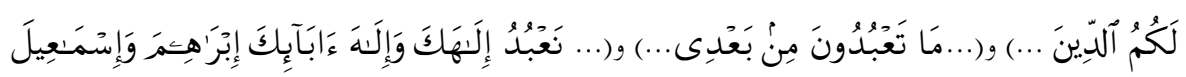

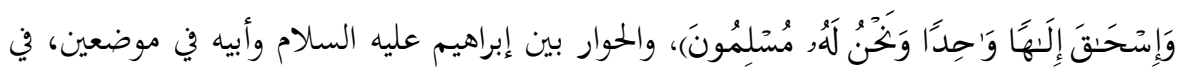

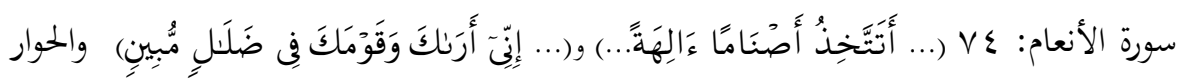

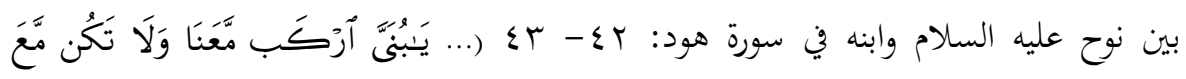

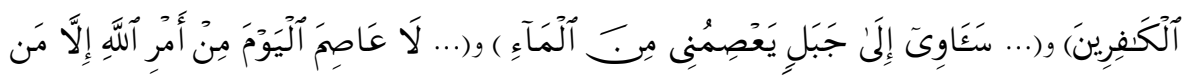
رَّحِمَ )، والجزء الأكبر من الحوار بين لقمان وابنه (، والحوار بين الابن الكافر ووالديه. فينبغي في 
العملية التربوية أن تلقى الموادا الدراسية عن توحيد الله ومعرفه صفاته. تبرز أهمية التوحيد في الحياة البشرية من أوجه متعددة، يتأكد بها أهمية العناية بتربية الناشئ عليها منها قبول العمل، والثبات

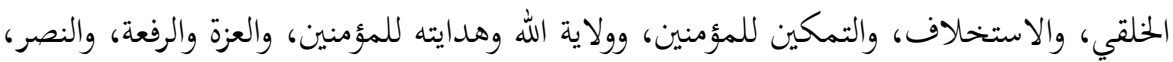
والأمن والطمأنينة. وإن للتوحيد آثارا تربوية على حياة وسلوك الإنسان، وتكون هذه الآثار بحسب القوة الإيمانية التي يحملها الفرد بين جوانحه وهي: ضابط للقلق النفسي، وضابط للدوافع النفسية، والثبات على المبدأ، وتحقيق التآخي الاجتماعي. r. الوعظ حول العبادات والأخلاق، في موضع واحد، جاء في بقية الحوار بين لقمان وابنه الذي احتوى موضوعا آخر. فينبغي في العملية التربوية أن تلقى الموادا الدراسية عن العبادات

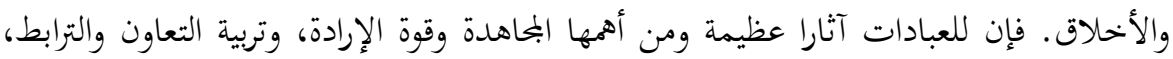
وتربية الفضائل، ووقاية من الانحرافات. وكذا قد اهتم الإسلام بالأخلاق الفاضلة، فكان هدفا

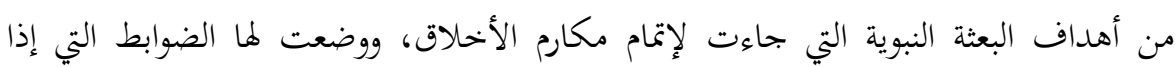
تمسك بها الأفراد والجماعات فازوا وبنوا من التيارات الهدامة.

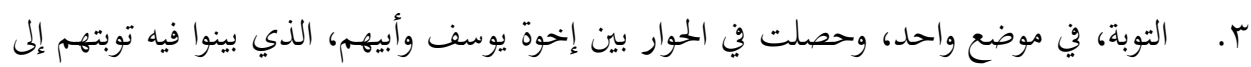
الله تعالى مما فعلوا بأخويهم وأبيهم. فينبغي في العملية التربوية أن تلقى الموادا الدراسية عن التوبة. لأن الإنسان محل الخطأ والنسيان، قد يرتكب الذنوب والمعاصي إلى الله ورسله وخلقه في حياته. لذالك كانت التوبة عملا لتمحو تلك الذنوب. ع. الاعتراف بنعمة الله تعالى وشكره عليها، في موضع واحد، وحصل في الحوار بين يوسف عليه

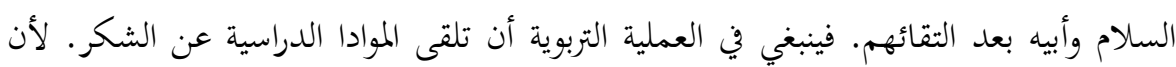
الله خلق الإنسان وأنعمه كثيرا، إن يعد الإنسان نعمة الله لايكصها. ولاسيما قد ذكر القرآن بأن يشكر الإنسان على الله ربه و والديه.

\section{ب- ناحية الطريقة التربوية}

يتنوع استخدام الأساليب أوالطرق في الحوار بين الآباء والأبناء في القرآن الكريم، وفق ما يقتضيه الموقف الحواري، في الموضوع أو الهدف المرجو من الحوار أو ما يناسب الطرف الآخر، ويحتاجه للوصول إلى النتيجة المطلوبة سواء كانت الإقناع أو تقريب وجهات النظر. وقد احتوت آيات الحوار على عدد من الأساليب والطرق التربوية، وتكرر استخدامها في أحيان كثيرة، وفيما يلي عرض لأهم هذه الأساليب والطرق والتعريف والفائدة المرجوة منها. 
عبد المحي

\section{1 النصح والمشاورة}

كان النصح والمشاورة من الموضوعات في الحوار بين الآباء والأبناء في القرآن الكريم التي تقع في

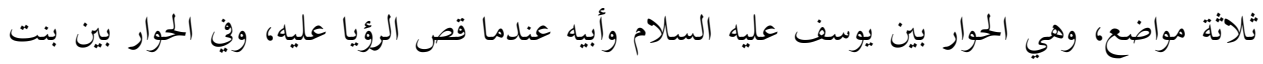

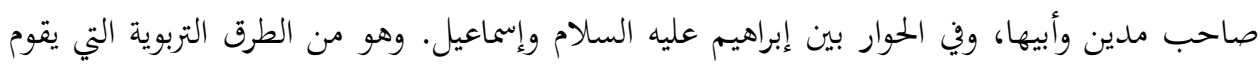
كمما الآباء والمدرسون لتربية الأبناء والطلاب.

r. الاستفهام أوالسؤال والجواب

الاستفهام هو طلب الفهم، وقد يخرج عن معناه الحقيقي-وهو طلب الفهم-فيكون استفهام

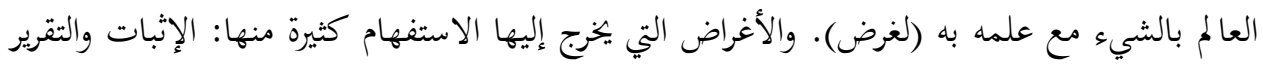
والأمر والإنكار والتحذير والتعجب (أحمد المطلوب:

من أمثلته: استفهام إخوة يوسف من أبيهم عن سبب منعه إرسال يوسف معهم: يَتَبَابَانَا مَا لَكَكَ

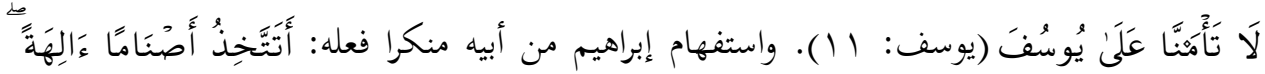
(الأنعام: ع V). وفي استخدام هذا الأسلوب في الحوار بين الآباء والأبناء إثارة إلى الإنكار أو إثارة

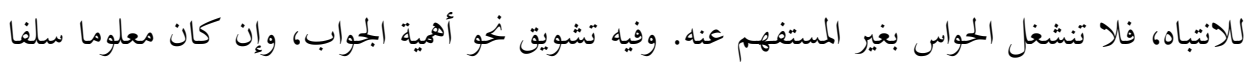

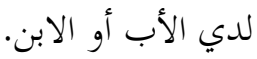

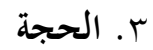

الدليل أو البرهان هو ما دل به على صحة الدعوى (ابن منظور: . . . ب). وهي أسلوب

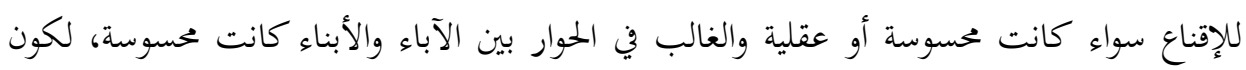

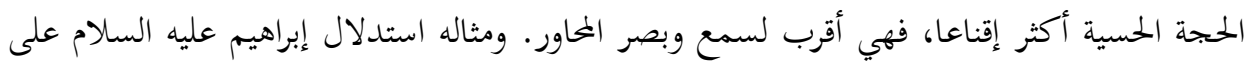

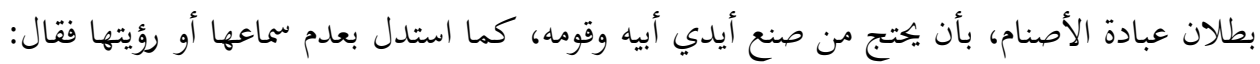

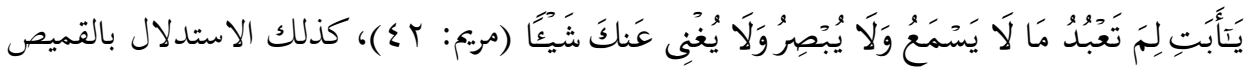

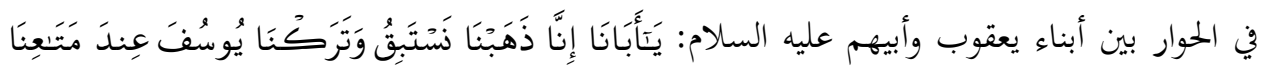

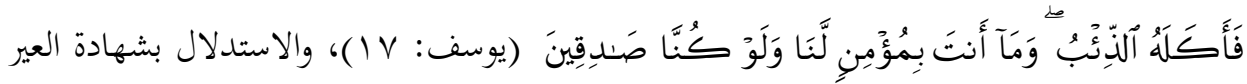

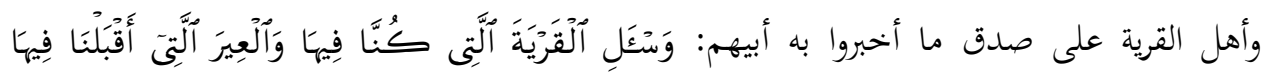
(يوسف:^r). 
ـ . النداء

وهو التصويت بالمنادى ليقبل أو هو طلب إقبال المدعو إلى الداعي (أحمد مطلوب: 997 1).

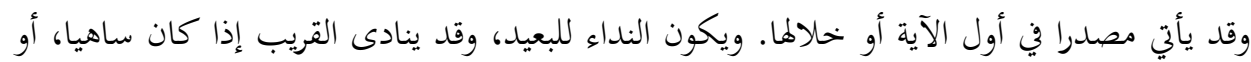
غافلا-تنزيلا له منزلة البعيد-وقوقدينادى القريب الذي ليس بساه، ولا غافل، إذا كان الخطاب المرتب على النداء في محل الاعتناء بشأن المنادى. ومن أغراضه أن يكون النداء للتأسف أو للتلهف أو للتنبيه أو للتحزن أو للتكريم والتلطف (الزركشي: وقد حصل النداء في آيات الحوار بين الآباء والأبناء مصاحبا لوصف البنوة مصغرا، إفرادا وجمعا، كذلك مصاحبا لوصف الأبوة، إفرادا وجمعا، ومن الأمثلة على ذلك: يابني: يَبَبَنَّ (البقرة:

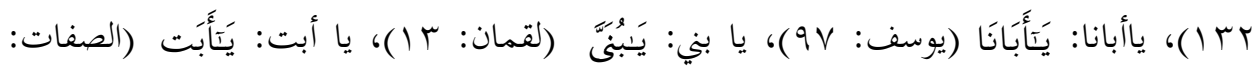

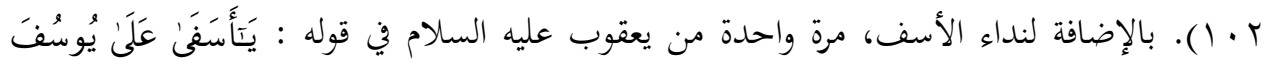
(يوسف: §) دلالة على التعجب، لأن الأسف لاينادى، والأصل أن النداء للأشخاص (الحازمي:

واستخدام النداء في الحوار مع حضور المنادى مستعمل بحازا في طلب حضور الذهن لوعي الكلام، وله أهمية خاصة في حوار الأب مع الابن، فالنداء كما جاء في آيات الحوار، اكتفى بأداة النداء (يا) مع لفظ البنوة مصغرا، دلالة على المحبة وإخحلاص النصح، وتنبيها على شدة قرب مكانة الابن من الأب، وقد اختلفت أغراض التصغير -كلمة بني- بحسب موضوع الحوار، فمرة يكون للتكويم والتلطف-كما كان من لقمان مع ابنه-، ومرة يكون لإظهار الحزن-كما كان من نوح مع ابنه-، وقد يكون لإظهار الشفقة والرحمة-كما كان من إبراهيم عليه السلام مع ابنه. وفي المقابل فإن أهمية النداء المصاحب للفظ الأبوة، وإن كان هو المعتاد في خطاب الأبناء مع الآباء، إلا أنه لم يأتي في حوار الأبناء

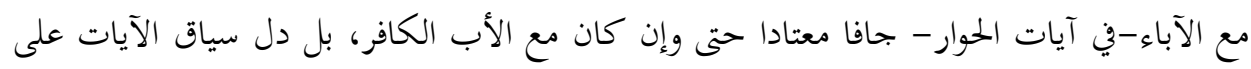
صدوره من الأبناء بنبرة الصوت التي تناسب موضوع الحوار، وبما يوافق الغرض من النداء،

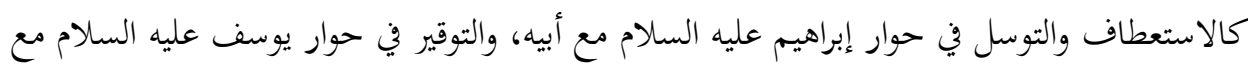
أبيه. ويلاحظ أن النداء قد يتكرر في الموقف الحواري الواحد أكثر من مرة كما حصل في حوار لقمان مع ابنه، وحوار إبراهيم عليه السلام مع أبيه، وي ذلك دلالة على فرط النصيحة وشدة الحرص، وإعادة تنشيط السامع. 
يقصد به الارتقاء التصاعدي في إكساب الفرد معالي الأمور؛ لأن النفوس تنفر عن ترك

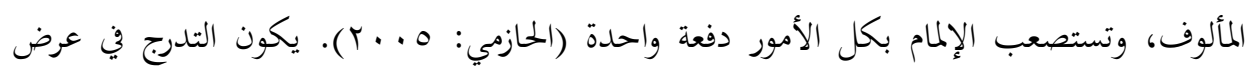

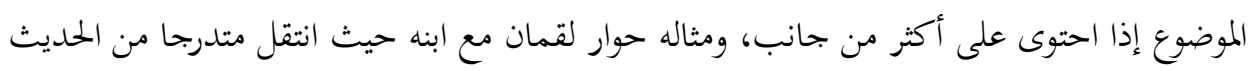

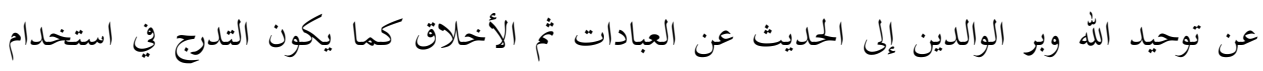

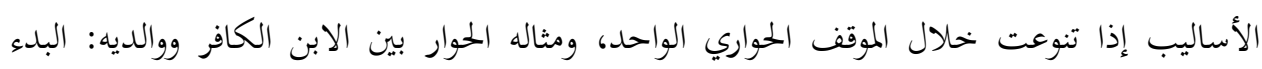

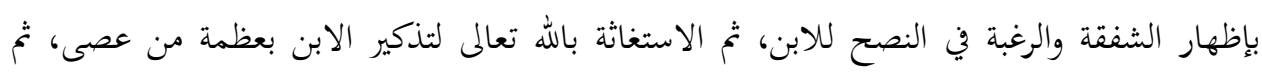

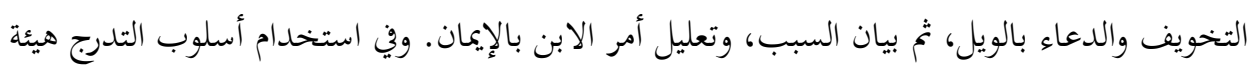

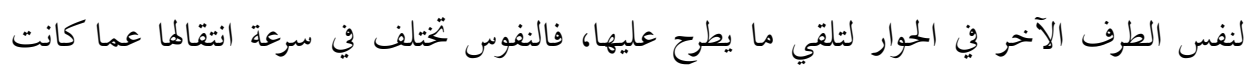

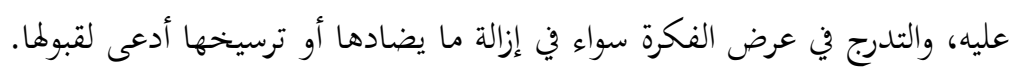

\section{צ. التعليل}

وهو أن تقصد إلى حكم فتراه مستبعدا لكونه قريبا أو عجيبا أو لطيفا أو نهو ذلك، فتأتي

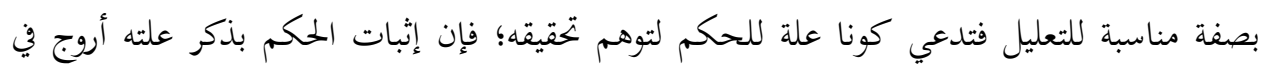
العقل من إثباته بمجرد دعواه (أحمد المطلوب:

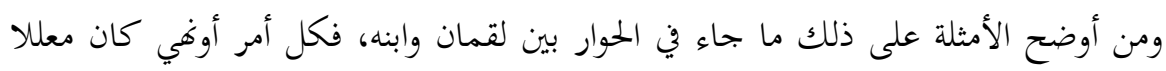

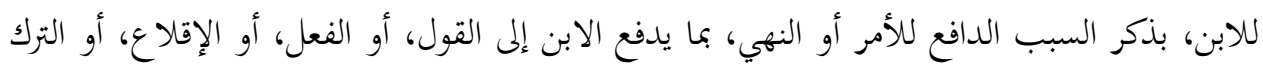

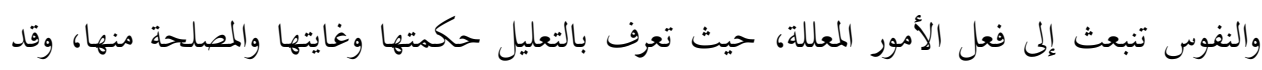

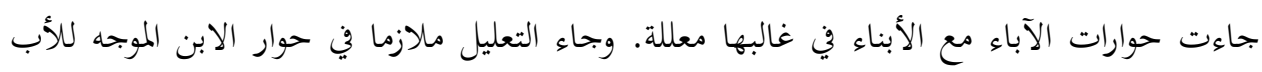

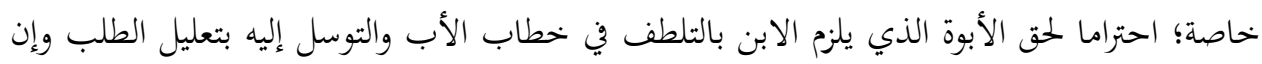
كان على حق.

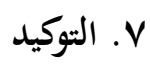

هو أن يرد اللفظ لتقرير المعنى الحاصل قبله وتقويته. ويدخل التوكيد في الكلام لدفع الشكر

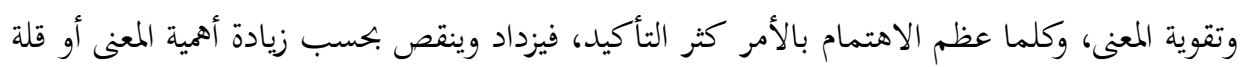

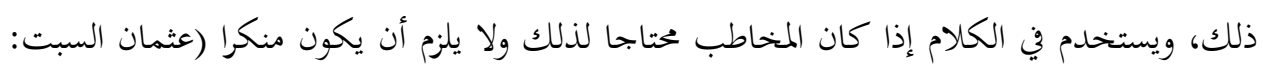
. (ه) \& I I 
وللتوكيد أدوات خاصة كاللام ونون التوكيد، ومنه التوكيد اللفظي ومنه المعنوي (الزركشي:

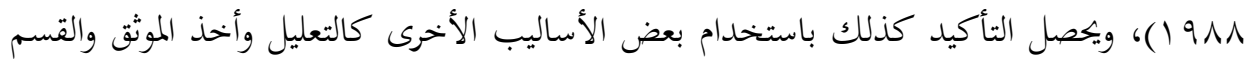

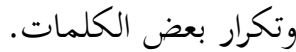

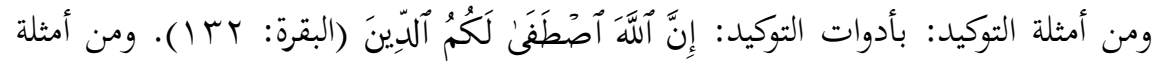

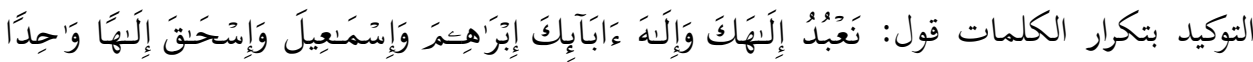

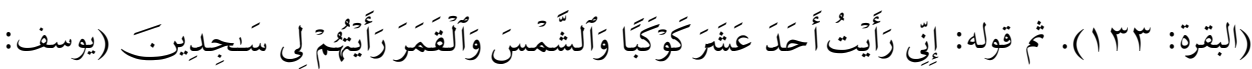

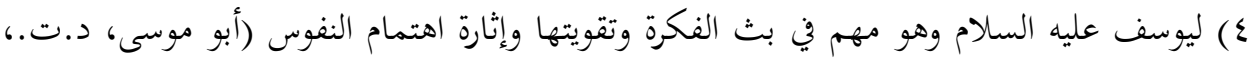

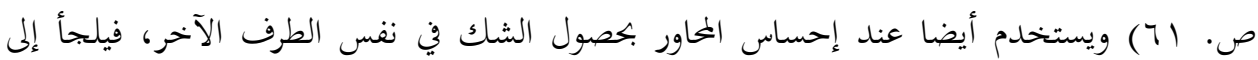
التوكيد في موضوع الحوار ليزيل هذا الشك، وقد استخدمه أبناء يعقوب عليه السلام، لتأكيد صدقهم في عدة مواقف حوارية، وإن كان غرضهم سيئا أحيانا.

1. - م. الموثق والإشهاد

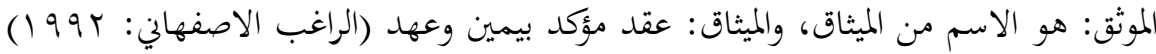
، وقد طلبه يعقوب عليه السلام من بنيه في حواره معهم، لما سألوه أخذ أخيهم بنيامين، فقال: لَنْ

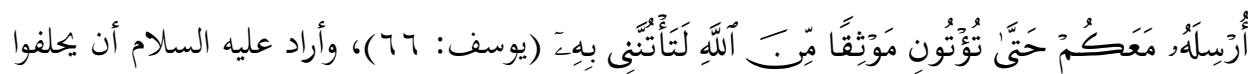
له بالله تعالى، وجعل الحلف به سبحانه موثقا منه؛ لأنه مما تؤكد العهود به وتشدد (الألوسي: .$(1910$

والإشهاد: هو أن يعتمد الأب على الله فيوكل أبناءه، وما أتوه من موثق إليه تعالى فهو الشاهد

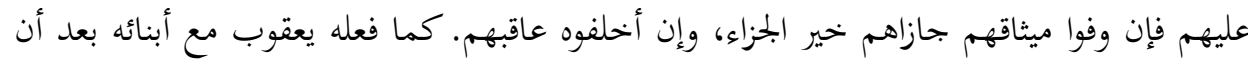

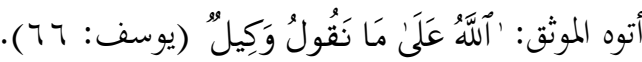
وطلب الممثث من الأبناء من الأساليب النافعة في دفع الابن لتحمل مسؤولية التكليف، إذا كان

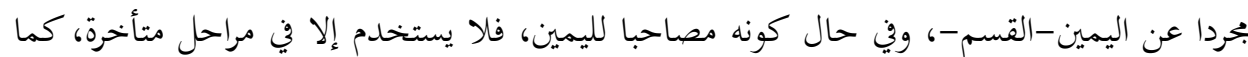

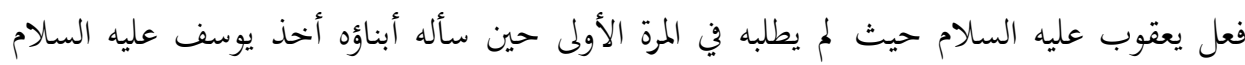
والمقصود منه تأكيد ثقة الأب بالله تعالى أمام أبنائه، وحث الأبناء على استحضار مراقبة الله

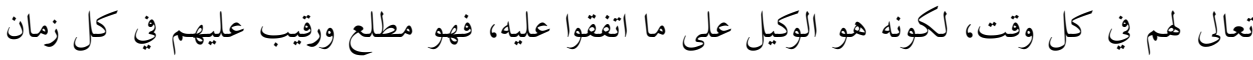


عبد المحي

ومكان. والملاحظ أن هذا الأسلوب أتى ثمرته مع أبناء يعقوب عليه السلام، حيث شعروا بمسؤولية هذا

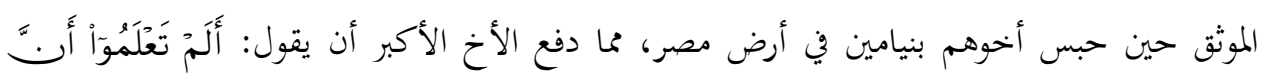

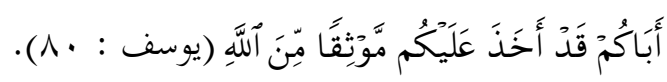

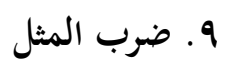

المثل: إبراز المعنى في صورة حسية تكسبه روعة وجمالا، وبتعله أكثر إمتاعا للعقل وإمتاعا للأذن سواء ورد هذا التمثيل بطريق الاستعارة، أو بطريقة التشبيه، أم بطريقة الكناية. وقرن الضرب بالمثل فقيل: “" ضرب المثل " اصطلاحا، فيكون معنى ضرب المثل هو صوغه وإنشاؤه وابتكاره (أبو حسين: 999 1 99 ). والمقصود من ضرب المثل: ربط المعاني إردة أو الجحيدة التي لا سابق خبرة للسامع، بأمر آخر مما يقع في خبرته، وبعملية قياس عقلي بسيطة سريعة، يمكن أن يصل المعنى المراد بكل سهولة ويسر

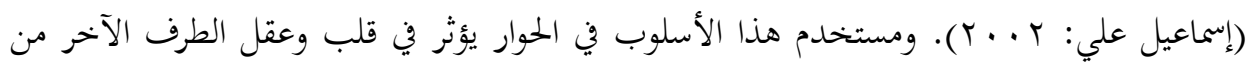
خلال الوقوف على وجحه الشبه، كمقدار الصغر-مثقال الحبة-في حوار لقمان مع ابنه، أو قباحة الفعل -كصوت الحمير - في نفس الحوار؛ وبذلك يتضح موضوع الحوار ويصل المقصود.

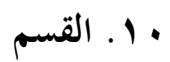

هو الحلف واليمين (عثمان السبت: إY | اهـ) ، ومنه ظاهر ومضمر، وفائدته تحقق الجواب

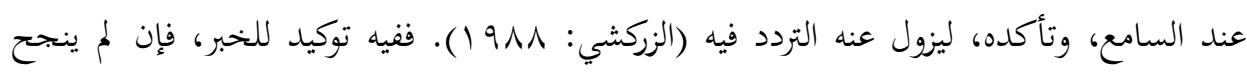
القسم أحيانا في مل المخاطب على التصديق، فإنه كثير ما يوهن في النفس الفكرة المخالفة، ويدفع إلى الشك فيها. وقد استخدم في الحوار بين الآباء والأبناء في القرآن الكريم خمس مرات فقط، ثناثلاث

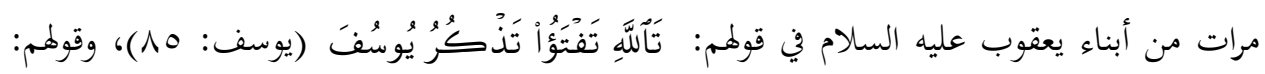

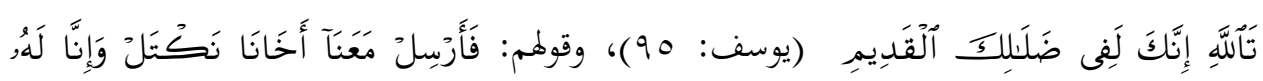

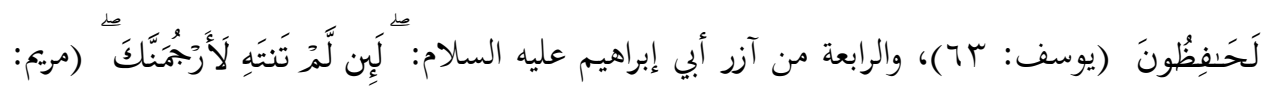

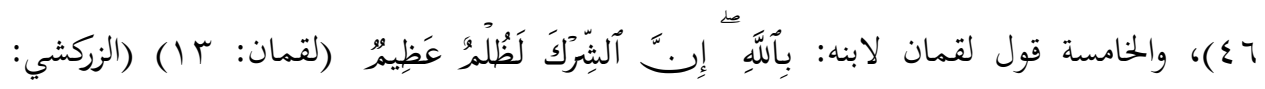
$\cdot(r \cdot . q$ 


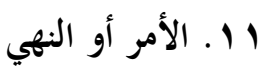

الأمر هو الصيغة الطالبة للفعل مطلقا من المخاطب (الحسيني: 1991) المهي والنهي هو طلب

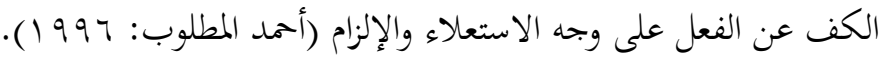

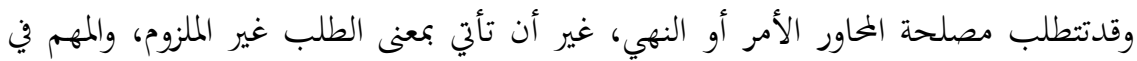
الحوار بين الآباء والأبناء، أوجاءت مرتبطة بالتعليل غالبا، لكون ذلك أقرب لاستجابة المحاور.

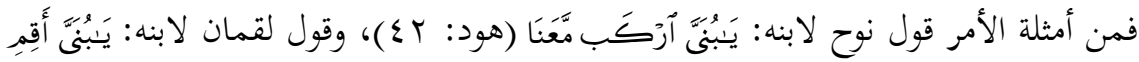

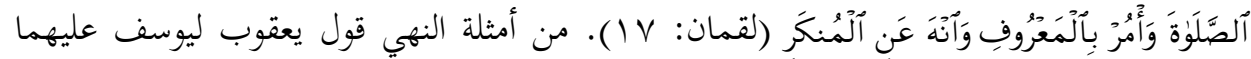

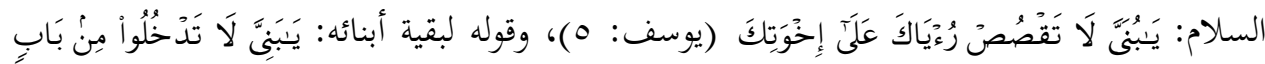
Le

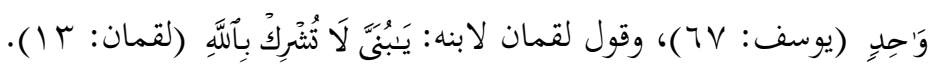

\section{r I أسلوب تقبيح الفعل السيئ في نظر المحاور لدفعه نحو تركه} وهو إظهار الفعل في صورة يستنكرها قلب وعقل الفاعل وتشمئز منها نفسه، من خلال الاستدلال على خطئه، بحجة عقلية، أو حسية، أو تشبيهه بأمر من الأمور المستقبحة. ومثاله: الحوار

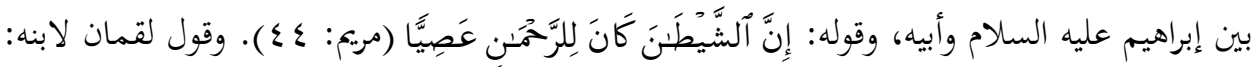

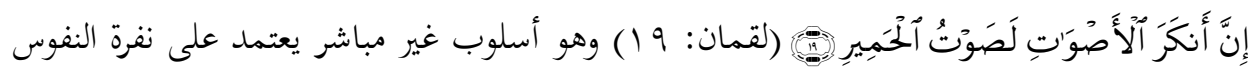
بفطر من القبيح، وميلها نهو الجميل من الأقوال والأفعال، وتظهر فائدته مع الأب، حفاظا على

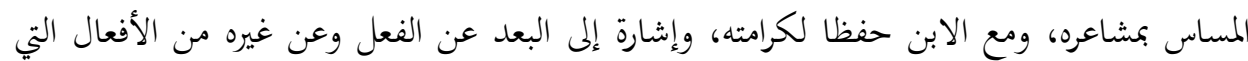
تماثله في السوء.

\section{ج. ت المية المعاملة والاتصال}

تميز الحوار بين الآباء والأبناء بقيامه على أسس متينة للتعامل والاتصال بين الآباء والابن أو

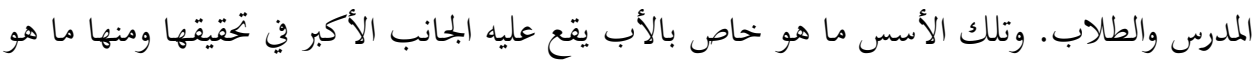
خاص بالابن وهو المسؤول عن وجودها ومنها ما هو عام مشترك يلزم حصوله من الأب والابن معا.

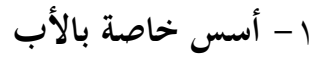

أ) حفظ كرامة الابن: من أعظم مقاصد القرآن الكريم ما يتعلق بتقرير وحفظ كرامة الإنسان

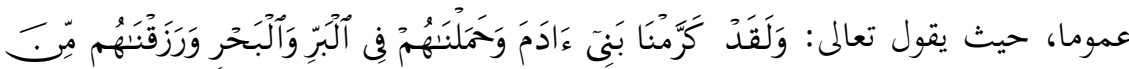


عبد المحي

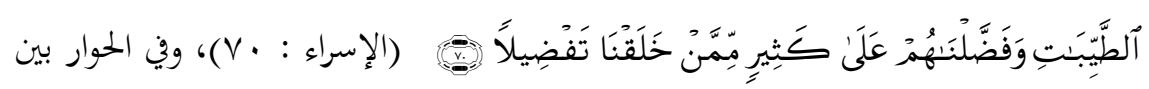
الآباء والأبناء، بحد أن الكرامة أساس تقوم عليه أغلب الحوارات، فقد ظهر من الآيات حفظ

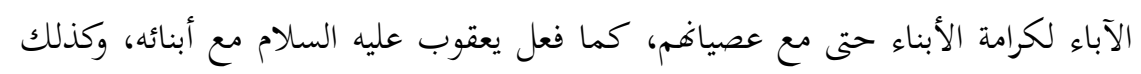
حفظها حتى مع كفرهم كما فعل نوح عليه السلام مع ابنه، لأن فيها دافع نحو الاستجابة والقبول.

ب) الإحاطة بالابن: تصوغ شخصية الابن عدد من المؤثرات، وتحيط ظروف مختلفة، تشكل تفكيره وتتحكم في فهمه وتصرفاته. والأب الذي يكرص على فهم الابن لابد أن يكون محيطا بكل هذه الأمور التي تؤثر فيه، ليتمكن من التعامل معه وفق خلفيته وما يتطلبه الموقف، ولعل أوضح مثال لهذا الأب هو يعقوب عليه السلام، فقد كان حواره مع أبنائه على الختلافهم

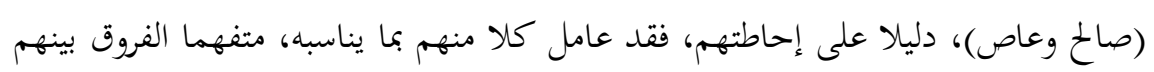

$$
\text { وحاجة كل منهم. }
$$

ج) عدم الاستهانة بالابن: على الأب في جميع أحوال الحوار مع الابن أن يظهر تقديره له، وتزداد

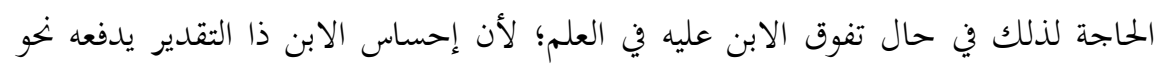

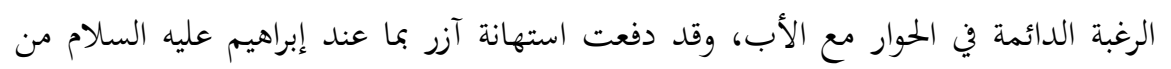
العلم وعدم استجابته لدعوته، إلى ترك إبراهيم عليه السلام له والبعد عنه.

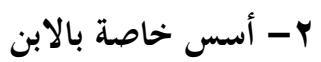

أ) الطاعة في الحق: من واجب البر أن يطيع الابن أباه في كل ما يأمر به، إلا أن يأمره بمعصية، ففي هذه الحالة يجب عليه عدم الطاعة، ومن ذلك ما حصل في حوار إبراهيم عليه السلام

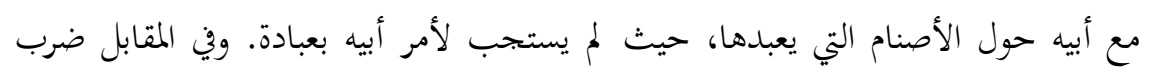

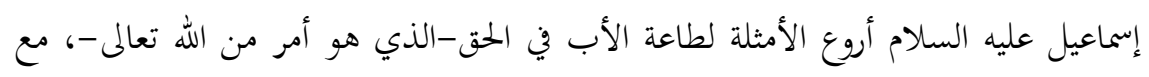
شدة الأمر الذي طلبه أبوه وهو ذبحه.

ب) الاستجابة السريعة: من الأمور التي تدل على وصول الحوار للنتيجة المطلوبة الاستجابة

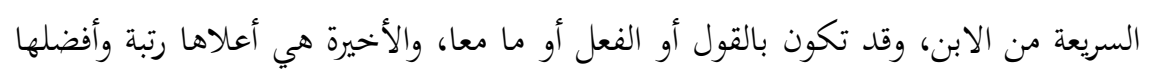
وقعا في نفس الأب، ومن أعظم الأمثلة على ذلك ما كان من إسماعيل عليه السلام، عندما ولها

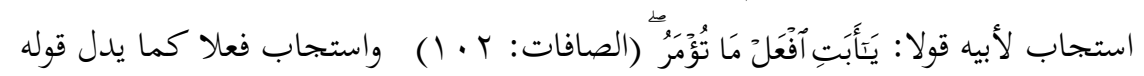




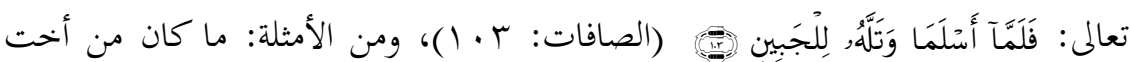

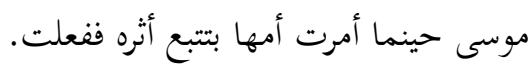

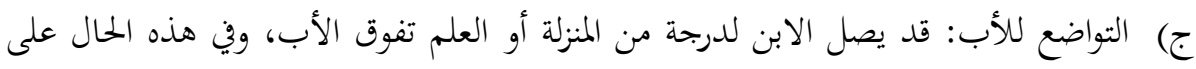

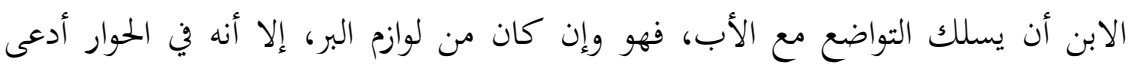

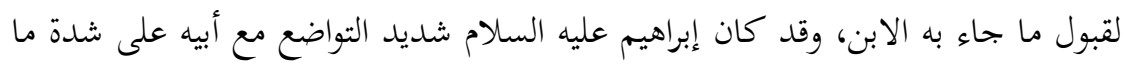
كان من أبيه من استكبار، وصدود، وكفر بالله تعالى؛ رغبة في استجابته لدعوة التوحيد.

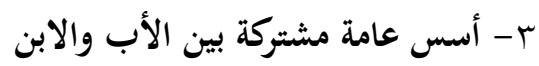
أ) التنوع في الخطاب وفق ما يحتاجه الموقف الحواري، فهذا إبراهيم عليه السلام يقف موقفين

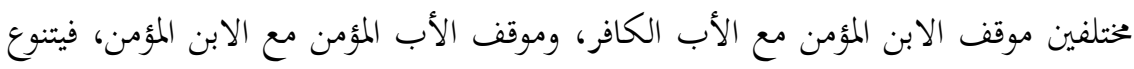
خطابه معهما وفق ما يناسب كلا منهما.

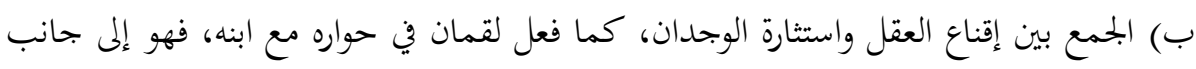

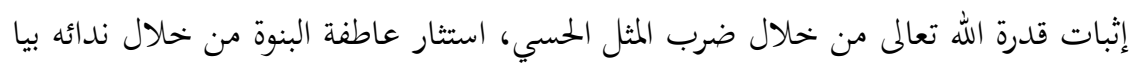
بني، دلالة على التحبب له والتلطف.

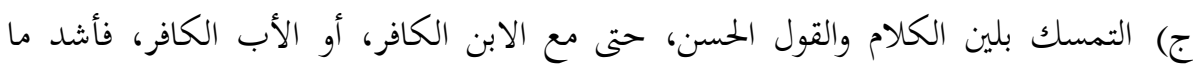

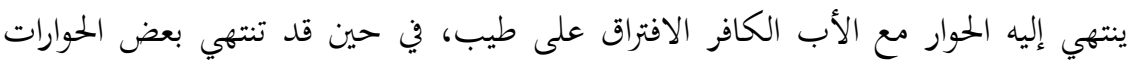

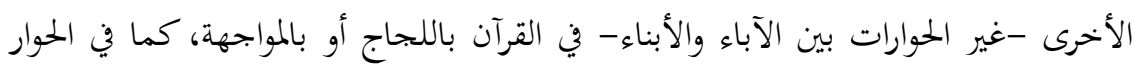

$$
\text { بين موسى وفرعون. }
$$

د) اختيار الألفاظ الأكثر مناسبة للمقام والموضوع، والأكثر وقعا في النفس: قول الأب لابنه

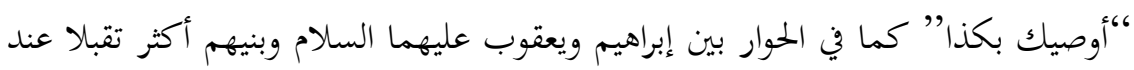

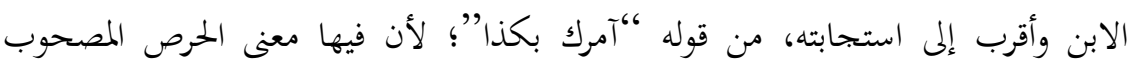

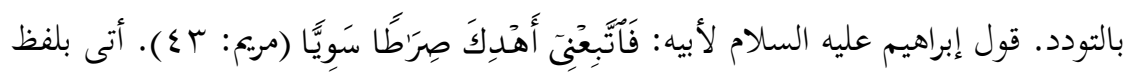

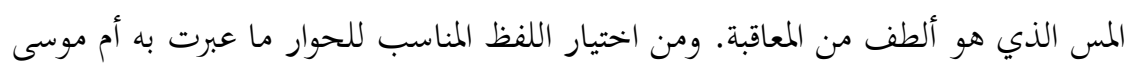

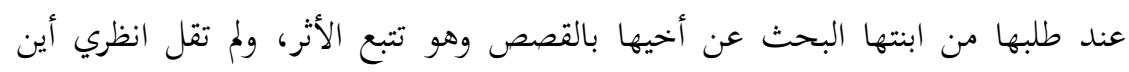

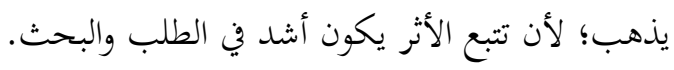

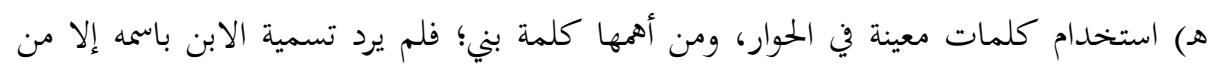
آزر لابنه إبراهيم عليه السلام. 
و) حق الحوار متاح لكل فرد في الأسرة، سواء الآباء أو الأبناء ذكورا وإناثا، الصالح والعاصي بل حتى الكافر. ز) أهمية الوقت والمكان في الحوار؛ لأن اختيار الوقت المناسب لموضوع الحوار أو المناسب لطري

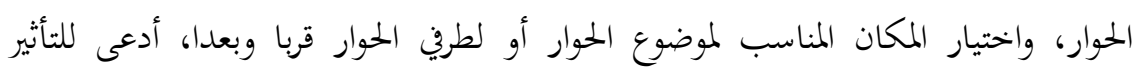

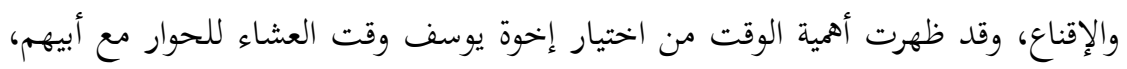

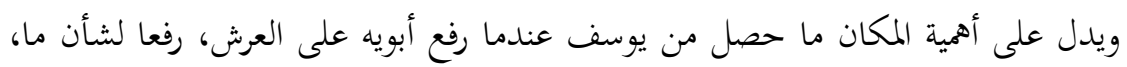
وتقريبا لمكان ما منه.

ح) العلاقة الوطيدة بين الآباء والأبناء، ضرورية لحصول التقارب في وجهات النظر، أو قبول

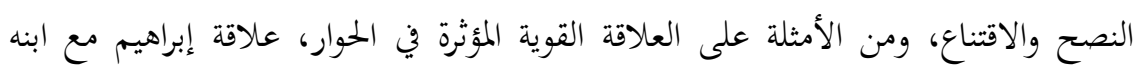

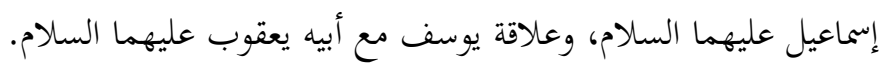

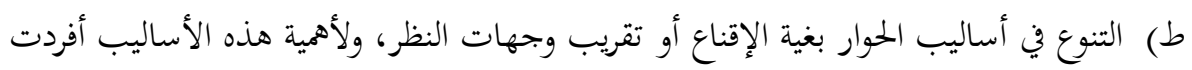
عن الأسس كجزء مستقل من أجزاء منهجية في الحوار بين الآباء والأبناء.

النتيجة

إن البحث عن القيم التربوية في الآيات القرآنية يجعل مبدأ رئيسيا لكشف الأصول التربوية من

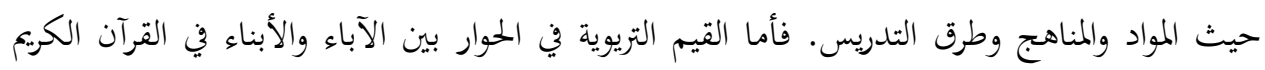

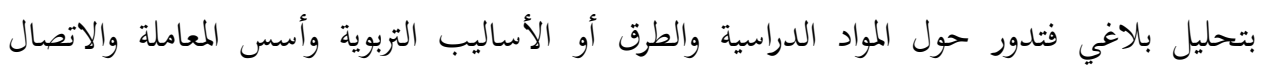

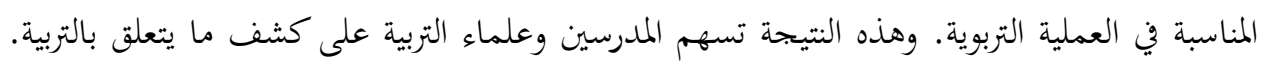

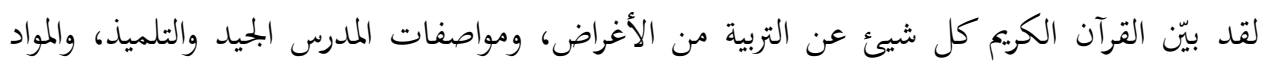
الدراسية، وطرق التدريس، ووظيفة الأسرة في التربية وأهمية البيئة المصطنعة في تربية الأولاد وغير ذلك الك.

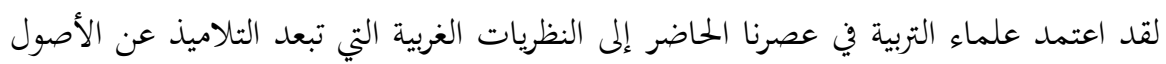
الديني. فيصبح التلاميذ بذلك صعيدين في الفكر والعلم والحضارة ولكن منخفضين في الشؤون الدينية.

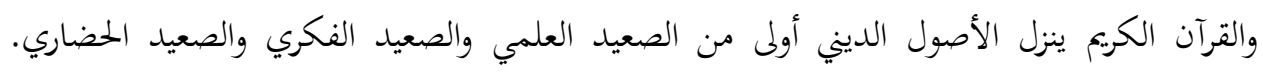

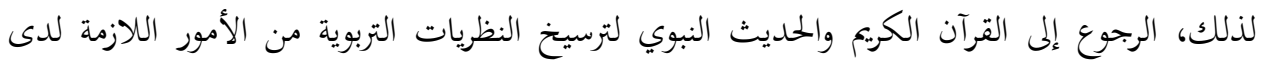
المسلمين، ولا سيما لتكوين الأجيال الصالحين في الفكر والعمل والحضارة. 


\section{المراجع}

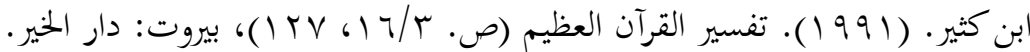

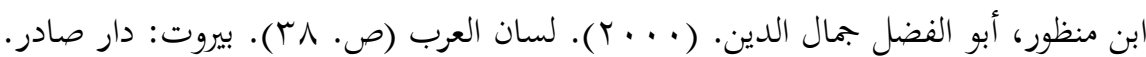

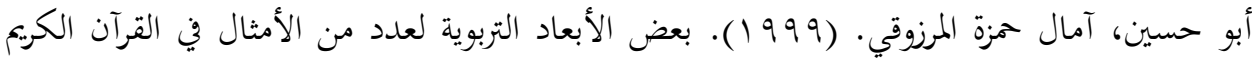

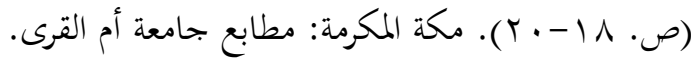

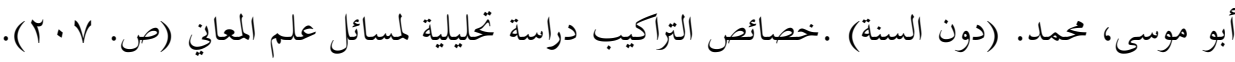

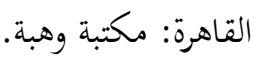

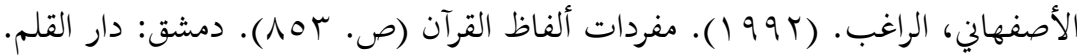

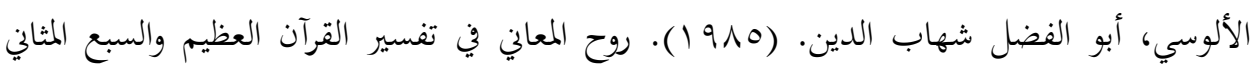
(ص. r ا / ع ). دار إحيا التراث العربي.

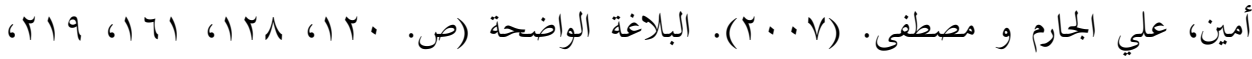

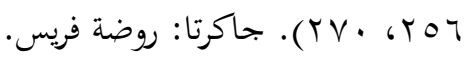

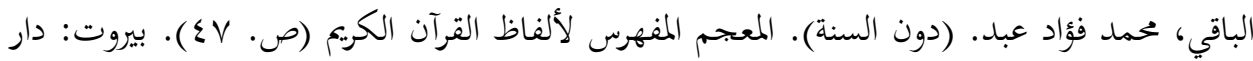

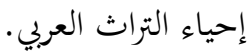

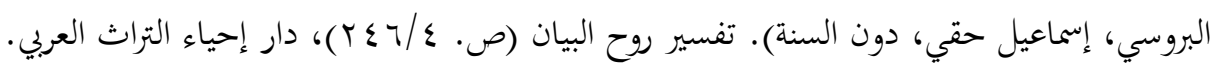

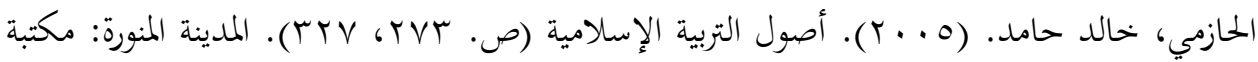

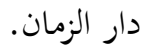

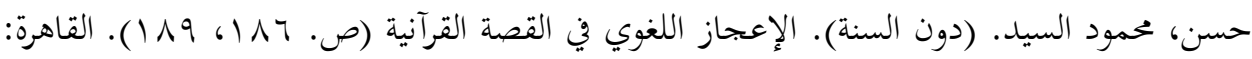

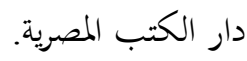

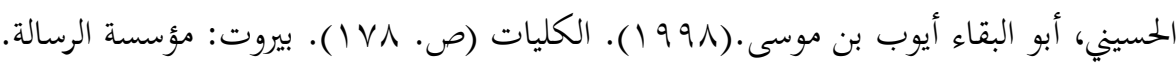

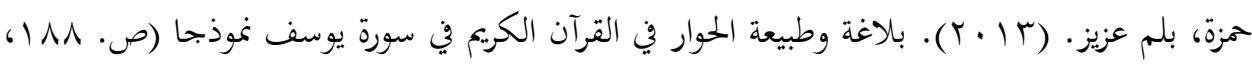
Y

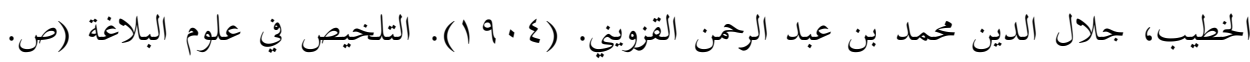

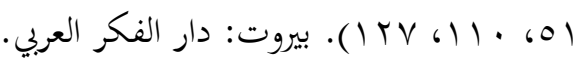

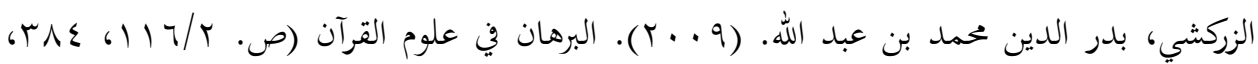

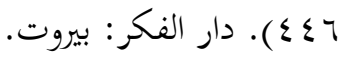


عبد المحي

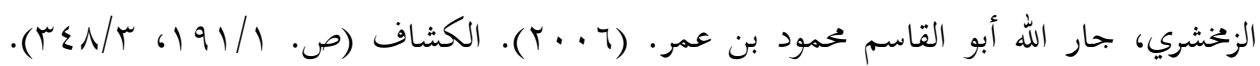
بيروت: دار الفكر.

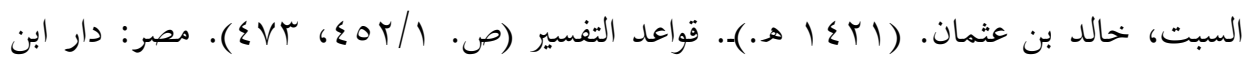
عفان.

الصابوني، محمد علي. (دون السنة). صفوة التفاسير (ص. . الصابوني.

طبانة، بدوي. (911 |). معجم البلاغة العربية (ص. |919). جدةة: دار المنارة.

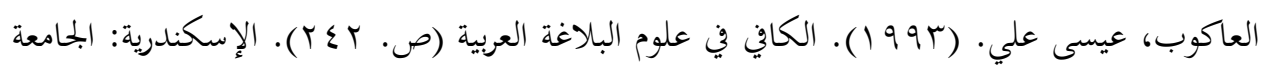
المفتوحة.

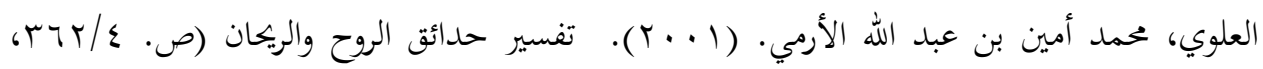

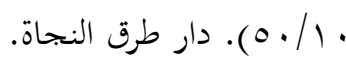

علي، سعيد إسماعيل، ( . . . Y). القرآن الكريم ورؤية تربوية (ص. بVT). القاهرة: دار الفكر العربي.

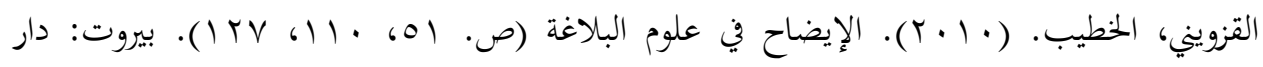
الكتب العلمية.

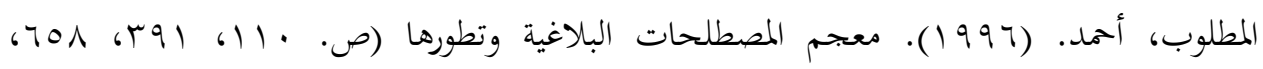
(7TV

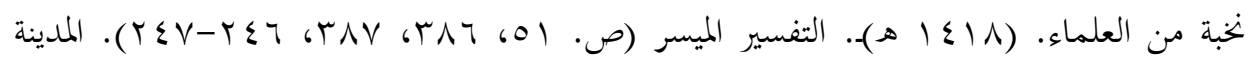
المنورة: بحمع الملك فهد لطباعة المصحف الشريف. الهاشمي، أحمد. (999 19). جواهر البلاغة (ص. 197 0، ع • 1). بيروت: المكتبة العصرية. 